
This report has ben reproduced directly from the best available copy.

Available to DOE and DOE contractors from the Office of Scientific and Technical Information, P.O. Box 62, Oak Ridge, TN 37831; prices available from (615) 576-8401, FTS 626-8401.

Available to the public from the National Technical Information Service, U.S. Department of Commerce, 5285 Port Royal Rd., Springfield, VA 22161.

This report was prepared as an account of work sponsored by an agency of the United States Government. Neither the United States Government nor any agency thereof, nor any of their employees, makes any warranty, express or implied, or assumes any legal liability or responsibility for the accuracy, completeness, or usefulness of any information, apparatus, product, or process disclosed, or represents that its use would not infringe privately owned rights. Reference herein to any specific commercial product, process, or service by trade name, trademark, manufacturer, or otherwise, does not necessarily constitute or imply its endorsement, recommendation, or favoring by the United States Government or any agency thereof. The views and opinions of authors expressed herein do not necessarily state or reflect those of the United States Government or any agency thereof. 


\section{DISCLAIMER}

Portions of this document may be illegible in electronic image products. Images are produced from the best available original document. 
Environmental Sciences Division

\title{
DESCRIPTION AND FIELD PERFORMANCE OF THE WALKER BRANCH THROUGHFALL DISPLACEMENT EXPERIMENT: 1993-1996
}

\author{
P. J. Hanson, D. E. Todd, M. A. Huston \\ Environmental Sciences Division \\ Oak Ridge National Laboratory \\ Oak Ridge, Tennessee 37831-6422 \\ J. D. Joslin \\ Tennessee Valley Authority \\ Norris, Tennessee 37828 \\ J. L. Croker and R. M. Augé \\ Institute of Agriculture \\ University of Tennessee \\ Knoxville, Tennessee 37901
}

Environmental Sciences Division

Publication No. 4753

Date Published: April 1998

Prepared for the

Office of Biological and Environmental Research

U.S. Department of Energy

Under budget and reporting code KP1203010

PREPARED BY

OAK RIDGE NATIONAL LABORATORY

managed by

LOCKHEED MARTIN ENERGY RESEARCH CORP.

for the

U.S. DEPARTMENT OF ENERGY

Under contract DE-AC05-96OR22464 



\section{CONTENTS}

Page

LIST OF FIGURES $\ldots \ldots \ldots \ldots \ldots \ldots \ldots \ldots \ldots \ldots \ldots \ldots \ldots \ldots \ldots \ldots \ldots \ldots$

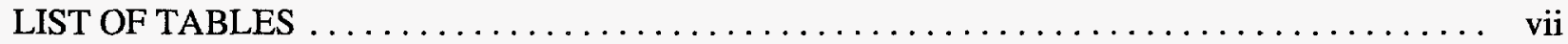

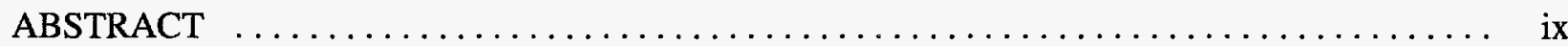

ACKNOWLEDGMENTS $\ldots \ldots \ldots \ldots \ldots \ldots \ldots \ldots \ldots \ldots \ldots \ldots \ldots \ldots \ldots \ldots \ldots \ldots \ldots$

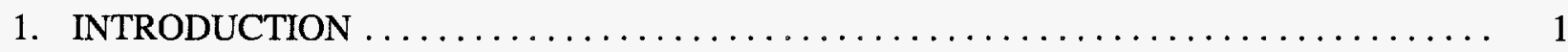

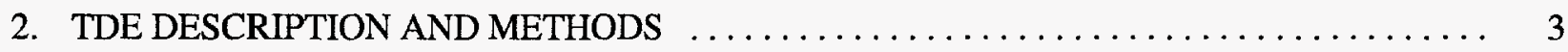

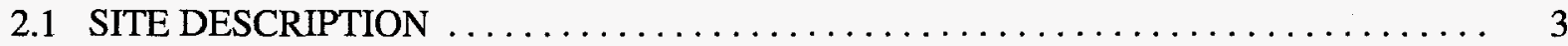

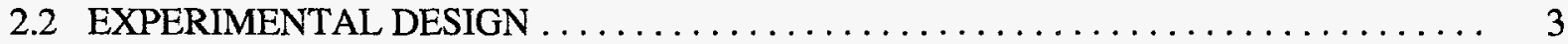

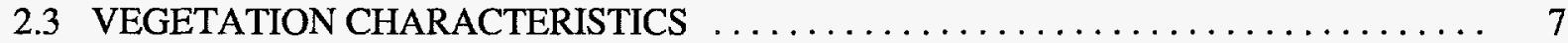

2.4 SOIL WATER MEASUREMENTS $\ldots \ldots \ldots \ldots \ldots \ldots \ldots \ldots \ldots \ldots \ldots \ldots \ldots \ldots \ldots \ldots$

2.5 SOIL WATER POTENTIAL ESTIMATES $\ldots \ldots \ldots \ldots \ldots \ldots \ldots \ldots \ldots \ldots \ldots \ldots \ldots$

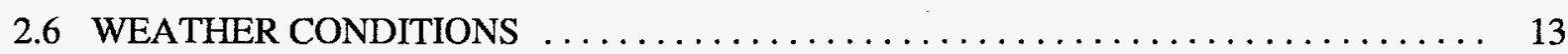

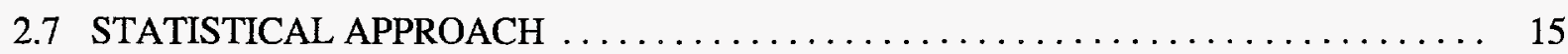

3. TDE PERFORMANCE AND DISCUSSION $\ldots \ldots \ldots \ldots \ldots \ldots \ldots \ldots \ldots \ldots \ldots \ldots \ldots \ldots$

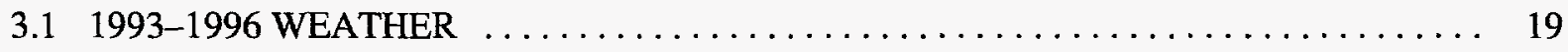

3.2 TDE IMPACTS ON VOLUMETRIC WATER CONTENT $\ldots \ldots \ldots \ldots \ldots \ldots \ldots \ldots$

3.3 TDE IMPACTS ON SOIL WATER POTENTIAL $\ldots \ldots \ldots \ldots \ldots \ldots \ldots \ldots \ldots \ldots \ldots$

3.4 ADEQUACY OF THE 80 - BY 80 -m PLOT SIZE $\ldots \ldots \ldots \ldots \ldots \ldots \ldots \ldots \ldots \ldots \ldots . \ldots \ldots$

3.5 TDE TEMPERATURE AND CHEMICAL IMPACTS $\ldots \ldots \ldots \ldots \ldots \ldots \ldots \ldots \ldots .28$

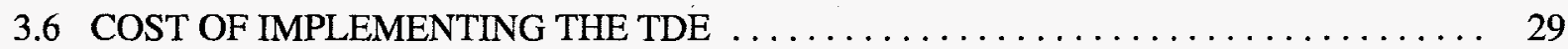

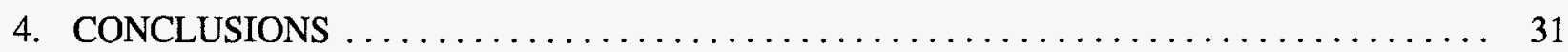

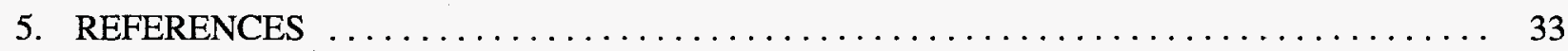

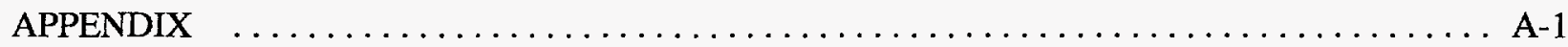





\section{LIST OF FIGURES}

Figure

Page

1 Schematic diagram of the trough and piping network responsible for transporting $\approx 33 \%$ of total throughfall from the dry experimental plot across the ambient plot to distribution pipes extending the width of the wet plot. . . . . . . . . . . . . . .

2 An aerial view of the horizontal species distribution of all trees greater than $0.1 \mathrm{~m}$ in diameter at dbh across the Throughfall Displacement Experiment as of 1996.

3 A side view of the vertical position of individual tree crowns for (A) upper, (B) middle, and (C) lower slope positions across the Throughfall Displacement Experiment.

4 Comparison of soil water content $(\mathrm{v} / \mathrm{v})$ obtained by means of time domain reflectometer and gravimetric approaches corrected for bulk density. . . . . . . . .

Soil moisture release curves for representative A, AE, and EB horizon soils of the Throughfall Displacement Experiment.

(A) Elevation map of the experimental area in meters and (B) contour plot showing the pretreatment pattern of soil water across the experimental site expressed relative to the mean for the entire experimental area.

7 The seasonal patterns of soil water content (\% v/v) from 1993 through 1996 for the 0 - to $0.35-\mathrm{m}$ and the 0.35 - to $0.7-\mathrm{m}$ soil depths. . . . . . . . . . . . .

Contour plots of the mean soil water content from 0 to $0.35 \mathrm{~m}$ across the Throughfall Displacement Experiment area throughout 1993.

Contour plots of the mean soil water content from 0 to $0.35 \mathrm{~m}$ across the Throughfall

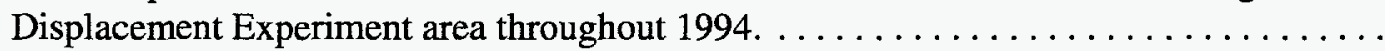

10 Contour plots of the mean soil water content from 0 to $0.35 \mathrm{~m}$ across the Throughfall Displacement Experiment area throughout $1995 . \ldots \ldots \ldots \ldots \ldots \ldots \ldots \ldots \ldots$

11 Contour plots of the mean soil water content from 0 to $0.35 \mathrm{~m}$ across the Throughfall Displacement Experiment area throughout $1996 . \ldots \ldots \ldots \ldots \ldots \ldots \ldots \ldots$

12 Soil water potentials from 1993 through 1996 for the 0 - to $0.35-\mathrm{m}$ and the 0.35- to $0.7-\mathrm{m}$ soil depths.

Soil water potential for the 0 - to $0.35-\mathrm{m}$ depth for the nine treatment and slope positions of the Throughfall Displacement Experiment throughout 1993, 1994, 1995, and 1996. 



\section{LIST OF TABLES}

Table

Page

1 Amounts of precipitation at the Throughfall Displacement Experiment:

(A) Monthly mmeasurements, annual totals, and long-term means, and

(B) Measurements or estimates for the ambient, wet treatment, and dry

treatment plots during the growing season (i.e., May through September)

2 Temperatures and cumulative amounts of radiation at the Throughfall Displacement Experiment and Walker Branch Watershed: (A) Mean monthly, growing-season (leaf-out to leaf-off), and annual temperatures and (B) cumulative monthly, growing-season, and annual radiation

3 Cumulative basal area of individual tree species $>0.1 \mathrm{~m} \mathrm{dbh}$ on each plot of the Throughfall Displacement Experiment site as of March 1994.

$4 \quad$ Number of individuals and cumulative basal area of each sapling species $<0.1 \mathrm{~m}$ dbh on each plot of the Throughfall Displacement Experiment site.

Coarse fraction volume percent by position and depth increment on the Throughfall Displacement Experiment site.

Mean litter surface and soil $(0.15 \mathrm{~m})$ temperatures $\left({ }^{\circ} \mathrm{C}\right)$ for each treatment area of the Walker Branch Throughfall Displacement Experiment on selected dates. 



\begin{abstract}
Hanson, P. J., D. E. Todd, M. A. Huston, J. D. Joslin, J. L. Croker, and R. M. Augé. 1998. Description and field performance of the Walker Branch Throughfall Displacement Experiment: 1993-1996. ORNL/TM-13586. Oak Ridge National Laboratory, Oak Ridge, Tennessee.

We are conducting a large-scale $\left(19,200-\mathrm{m}^{2}\right)$ manipulative field experiment in an upland oak forest on the Walker Branch Watershed in eastern Tennessee to identify important ecosystem responses that might result from future precipitation changes. The manipulation of soil water content is being implemented by a gravity-driven transfer of throughfall from one $6400-\mathrm{m}^{2}$ treatment plot to another. Throughfall is intercepted in $\approx 1850$ subcanopy troughs $(0.3 \times 5 \mathrm{~m})$ suspended above the forest floor of the 'dry' plot ( $\approx 33 \%$ of the ground area is covered) and transferred by gravity flow across an ambient plot for subsequent distribution onto the 'wet' treatment plot. Soil water content is being monitored at two depths ( 0 to 0.35 and 0.35 to $0.7 \mathrm{~m}$ ) with time domain reflectometers at 310 sampling locations across the site. The experimental system is able to produce statistically significant differences in soil water content in years having both dry and wet conditions. Maximum soil water content differentials between wet and dry plots in the 0 - to $0.35-\mathrm{m}$ soil horizon were 8 to $10 \%$ during summers with abundant precipitation and 3 to $5 \%$ during drought periods. Treatment impacts on soil water potential were restricted to the surface soil layer. Comparisons of pre- and post-installation soil and litter temperature measurements showed the ability of the experimental design to produce changes in soil water content and water potential without creating large artifacts in the forest understory environment.
\end{abstract}





\section{ACKNOWLEDGMENTS}

The authors thank James Arnett, Nelson Edwards, Howard Marotto, Michael Hayes, Kristin Harter, Todd Tabberer, Tracy Misek, Benjamin Stringfellow, and Stan Wullschleger for their valuable assistance in the collection of the field data. We also acknowledge the contributions of Stan Wullschleger, Jeff Amthor, and several anonymous ad hoc reviewers for providing comments on an early version of this paper. The research was sponsored by the Program for Ecosystem Research within the U.S. Department of Energy's Environmental Sciences Division, Office of Biological and Environmental Research. The research was conducted on the Oak Ridge National Environmental Research Park. 



\section{INTRODUCTION}

The Intergovernmental Panel on Climate Change (IPCC) concluded that climate changed over the past century, that human activities have had an influence on these changes, and that climate is expected to continue to change in the future (Houghton et al. 1996). Depending on the emission scenarios assumed, continued increases in the levels of greenhouse gases in the atmosphere are expected to induce an additional 1 to $3.5^{\circ} \mathrm{C}$ increase in average global surface temperatures by the year 2100 (Kattenburg et al. 1996). These temperature increases are expected to modify global hydrologic budgets, leading to increased winter precipitation at high latitudes, more hot days and fewer cold days, and more or fewer droughts or floods, depending on location (Kattenburg et al. 1996; Rind et al. 1990). These predicted changes in climate have raised concerns about potential impacts on terrestrial ecosystem productivity, biogeochemical cycling, and the availability of water resources (Kirschbaum and Fischlin 1996; Melillo et al. 1990, 1996).

The responses of forests to decreased water availability or increased occurrence of drought is currently considered a key issue in climate change scenarios (Wigley et al. 1984). Nielson et al. (1989), concluded that forests throughout the United States could experience severe impacts from climate change, especially in the southern states, where potential evapotranspiration is predicted to increase the most (Smith and Tirpak 1989). Concerns regarding vegetation impacts have been amplified because rates of change are expected to occur much faster than past successional processes and species dispersal rates (Davis 1989; Overpeck et al. 1991; Pastor and Post 1988; Solomon 1986). The actual directions and magnitude of expected changes in precipitation are highly uncertain, and specific scenarios for regional climate change are only preliminary (Cooter et al. 1993; Mohnen and Wang 1992; Rind et al. 1992; Schneider 1989).

Controlled experiments in greenhouses and growth chambers provide us with a large database of information concerning the impacts of moisture manipulations on the physiology and growth of forest tree seedlings and saplings (e.g., Ellsworth and Reich 1992; Hinckley et al. 1978; Kleiner et al. 1992; Kolb et al. 1990; Pezeshki and Chambers 1986), but concerns remain as to the appropriateness of the extrapolation of such data to mature tree responses in forest stands, where our understanding is limited largely to short-term responses to water stress (Cregg et al. 1989; Hinckley et al. 1978) or to a limited number of trees (Dougherty and Hinckley 1981; Epron et al. 1992; Ginter-Whitehouse et al. 1983). Manipulative field experiments can play a role in the identification of important ecosystem responses that might result from future precipitation changes.

Recent review articles (Graham et al. 1990; Mooney 1991; Mooney et al. 1991; Woodward 1992) have called for large-scale manipulation experiments to adequately address the impacts of changing climates on ecosystems. This paper describes the Walker Branch Throughfall Displacement Experiment (TDE) and evaluates its field performance from 1993 through 1996 . The TDE is a $19,200-\mathrm{m}^{2}$ field manipulation experiment developed for mechanistic studies of the adaptation and acclimation of organisms to changing precipitation conditions. The goal of the TDE experiment is to develop a mechanistic understanding of how forest ecosystem organisms adjust to changes in precipitation inputs. Preliminary discussions of the TDE and its performance can also be found in papers by Turner et al. (1993) and Hanson et al. (1995). 



\section{TDE DESCRIPTION AND METHODS}

\subsection{SITE DESCRIPTION}

The TDE is located on the Walker Branch Watershed $\left(35^{\circ} 58^{\prime} \mathrm{N}\right.$ and $\left.84^{\circ} 17^{\prime} \mathrm{W}\right)$, a part of the U.S. Department of Energy's (DOE's) National Environmental Research Park near Oak Ridge, Tennessee (Johnson and Van Hook 1989). Long-term mean annual precipitation is $1358 \mathrm{~mm}$ (Table 1), and mean temperature is $14.1^{\circ} \mathrm{C}$ (Table 2). The acidic forest soils (pH 3.5 to 4.6) are primarily Typic Paleudults. These ancient residual soils are cherty silt loams that are infertile and highly permeable. They formed over a dolomitic bedrock but retain little evidence of their carbonate parent material. Depth to bedrock at this location is approximately $30 \mathrm{~m}$. The past 25 years of research on the Walker Branch Watershed (Johnson and Van Hook 1989) provide an important reference database against which to judge the outcomes of the our large-scale manipulation.

The TDE experimental site was chosen because of its uniform slope, consistent soils, and a reasonably uniform distribution of vegetation. The experimental area was located at the upper divide of the watershed so that lateral flow of water into the soils at the top of the treatment area would not confound attempts to create the modified soil water treatments. The site was chosen to have a southern aspect so that the impacts of the reduced moisture treatment would be increased under greater net radiation levels.

\subsection{EXPERIMENTAL DESIGN}

The manipulations of throughfall reaching the forest floor are made with a system designed to transfer precipitation passively from one experimental plot to another (Fig. 1). One advantage of our passive design is that all modifications of ambient throughfall are conducted in real time so that they are coordinated with appropriate atmospheric conditions (i.e., artificial rainfall is not added under highlight-low-humidity conditions). Throughfall precipitation is intercepted in $\sim 1850$ subcanopy troughs suspended above the forest floor of the 'dry' plots ( $-33 \%$ of the ground area in the dry plot is covered in this $\left.6400-\mathrm{m}^{2} \mathrm{plot}\right)$. The throughfall is then transferred by gravity flow across an ambient plot $\left(6400 \mathrm{~m}^{2}\right)$ and distributed onto the 'wet' treatment plot $\left(6400 \mathrm{~m}^{2}\right)$ through paired drip holes spaced approximately $1 \mathrm{~m}$ apart. The troughs are arranged in 21 rows of $\sim 90$ troughs. Although stemflow is expected to contribute as much as $10 \%$ of the precipitation reaching the forest floor in heavy rain events, depending on species, tree size, season and storm dynamics, collection and transfer of stem flow were not included in the current design (Ragsdale et al. 1992).

The individual throughfall collection troughs $(0.3 \times 5 \mathrm{~m})$ are made of 6-mil greenhouse-grade polyethylene, and they are installed at variable angles, depending on their position on the slope. The lower and upper ends of each trough are approximately 1.5 and $2.5 \mathrm{~m}$ off of the ground, respectively. The average ground area covered by each trough is less than each trough's total area because of their sloped installation.

The polyethylene troughs are supported on a frame of $\sim 20-\mathrm{mm}$ galvanized electrical metallic conduit and attached with large ( $25.4-\mathrm{mm})$ binder clips (Charles Leonard Inc., Glendale, New York). Standard aluminum gutters $(\sim 150 \mathrm{~mm}$ wide) positioned directly below the trough outlets collected the throughfall from a series of troughs. The troughs and gutters were constructed in 12.2-m modular sections so that damaged (wind and/or fallen large branches) sections would not compromise throughfall interception and transfer of an entire collection line. Water collected in each modular trough/gutter assembly was drained via a reinforced flexible hose into a continuous $160-\mathrm{m}$ pipeline made of $\sim 100-\mathrm{mm}$ schedule 40 PVC. This pipeline served as the storage container and transfer pipeline for the collected throughfall. The distribution pipeline laid out across the wet plot was constructed of $\sim 50-\mathrm{mm}$ schedule 40 PVC pipe. 
Table 1. Amounts of precipitation at the Throughfall Displacement Experiment:

(A) Monthly measurements, annual totals, and long-term means, and

(B) Measurements or estimates for the ambient, wet treatment, and dry treatment plots during the growing season (i.e., May through September)

\begin{tabular}{|c|c|c|c|c|c|c|}
\hline \multirow{2}{*}{ Parameter } & \multicolumn{5}{|c|}{ Year } & \multirow{2}{*}{$\begin{array}{l}\text { Mean for } \\
1949-1996\end{array}$} \\
\hline & 1992 & 1993 & 1994 & 1995 & 1996 & \\
\hline & \multicolumn{6}{|c|}{ A. Monthly ambient plot precipitation $(\mathrm{mm})$} \\
\hline January & 86 & 101 & 142 & 135 & 171 & 129 \\
\hline February & 83 & 50 & 249 & 97 & 37 & 118 \\
\hline March & 96 & 173 & 254 & 94 & 147 & 143 \\
\hline April & 42 & 105 & 226 & 64 & 103 & 104 \\
\hline May & 58 & 68 & 59 & 175 & 177 & 110 \\
\hline June & 102 & 15 & 194 & 55 & 178 & 104 \\
\hline July & 130 & 81 & 128 & 47 & 259 & 132 \\
\hline August & 86 & 93 & 106 & 15 & 68 & 96 \\
\hline September & 79 & 126 & 82 & 102 & 101 & 94 \\
\hline October & 67 & 50 & 64 & 128 & 40 & 76 \\
\hline November & 144 & 95 & 98 & 132 & 214 & 114 \\
\hline December & 147 & 182 & 73 & 92 & 143 & 140 \\
\hline \multirow[t]{2}{*}{ Annual total } & 1118 & 1139 & 1675 & 1135 & 1638 & 1358 \\
\hline & \multicolumn{6}{|c|}{ B. Growing-season precipitation (mm) } \\
\hline Ambient plot & 454 & 383 & 569 & 394 & 783 & 534 \\
\hline Wet plot & - & - & $\sim 759$ & $\sim 525$ & $\sim 1044$ & - \\
\hline Dry plot & - & - & -379 & $\sim 263$ & $\sim 522$ & - \\
\hline
\end{tabular}


Table 2. Temperatures and cumulative amounts of radiation at the Throughfall Displacement Experiment and Walker Branch Watershed: (A) Mean monthly, growing-season (leaf-out to leaf-off), and annual temperatures and (B) cumulative monthly, growing-season, and annual radiation

\begin{tabular}{|c|c|c|c|c|c|c|}
\hline \multirow{2}{*}{ Parameter } & \multicolumn{5}{|c|}{ Throughfall Displacement Experiment } & \multirow{2}{*}{$\begin{array}{c}\text { Walker Branch } \\
\text { Watershed } \\
\text { 1951-1996 }\end{array}$} \\
\hline & 1992 & 1993 & 1994 & 1995 & 1996 & \\
\hline & \multicolumn{6}{|c|}{ A. Mean temperatures $\left({ }^{\circ} \mathrm{C}\right)$} \\
\hline January & 4.0 & 5.6 & -0.2 & 3.4 & 1.8 & 2.5 \\
\hline February & 7.1 & 3.7 & 5.9 & 4.0 & 4.0 & 4.5 \\
\hline March & 8.6 & 7.5 & 8.6 & 11.8 & 6.6 & 8.9 \\
\hline April & 14.7 & 12.8 & 15.4 & 16.0 & 13.1 & 14.3 \\
\hline May & 17.6 & 19.6 & 16.5 & 19.1 & 20.5 & 18.9 \\
\hline June & 21.9 & 23.7 & 23.8 & 22.4 & 23.0 & 23.0 \\
\hline July & 25.2 & 27.8 & 24.8 & 25.5 & 23.7 & 24.9 \\
\hline August & 22.9 & 25.9 & 24.0 & 25.7 & 23.6 & 24.4 \\
\hline September & 21.6 & 22.1 & 19.7 & 20.6 & 19.5 & 21.0 \\
\hline October & 14.1 & 15.4 & 15.6 & 14.7 & 14.8 & 14.6 \\
\hline November & 8.3 & 7.9 & 11.4 & 6.2 & 6.5 & 8.5 \\
\hline December & 3.8 & 4.2 & 7.1 & 3.1 & 5.7 & 4.1 \\
\hline Growing season & 18.3 & 19.7 & 20.0 & 19.3 & 19.5 & $\mathrm{NA}^{a}$ \\
\hline \multirow[t]{2}{*}{ Annual } & 14.2 & 14.8 & 14.4 & 14.4 & 13.6 & 14.1 \\
\hline & \multicolumn{6}{|c|}{ B. Cumulative radiation $\left(M J \mathrm{~m}^{-2}\right)$} \\
\hline January & $\mathrm{NA}^{a}$ & 186 & 158 & 192 & 145 & $\mathrm{NA}^{a}$ \\
\hline February & $\mathrm{NA}^{a}$ & 241 & 254 & 246 & 234 & $\mathrm{NA}^{a}$ \\
\hline March & $\mathrm{NA}^{a}$ & 281 & 373 & 465 & 402 & $\mathrm{NA}^{a}$ \\
\hline April & 574 & 476 & 518 & 545 & 503 & $\mathrm{NA}^{a}$ \\
\hline May & 550 & 580 & 635 & 526 & 624 & $\mathrm{NA}^{a}$ \\
\hline June & 537 & 612 & 550 & 587 & 622 & $\mathrm{NA}^{a}$ \\
\hline July & 559 & 656 & 517 & 654 & 556 & $\mathrm{NA}^{a}$ \\
\hline August & 484 & 548 & 483 & 551 & 572 & $\mathrm{NA}^{a}$ \\
\hline September & 399 & 434 & 459 & 398 & 404 & $\mathrm{NA}^{a}$ \\
\hline October & 308 & 320 & 360 & 365 & 378 & $\mathrm{NA}^{a}$ \\
\hline November & 191 & 215 & 268 & 218 & 207 & $\mathrm{NA}^{a}$ \\
\hline December & 131 & 174 & 163 & 212 & 177 & $\mathrm{NA}^{a}$ \\
\hline Growing season & 3403 & 3570 & 3497 & 3658 & 3488 & $\mathrm{NA}^{a}$ \\
\hline Annual & $\mathrm{NA}^{a}$ & 4724 & 4737 & 4960 & 4824 & $\mathrm{NA}^{a}$ \\
\hline
\end{tabular}

${ }^{a} \mathrm{NA}=$ not available. 


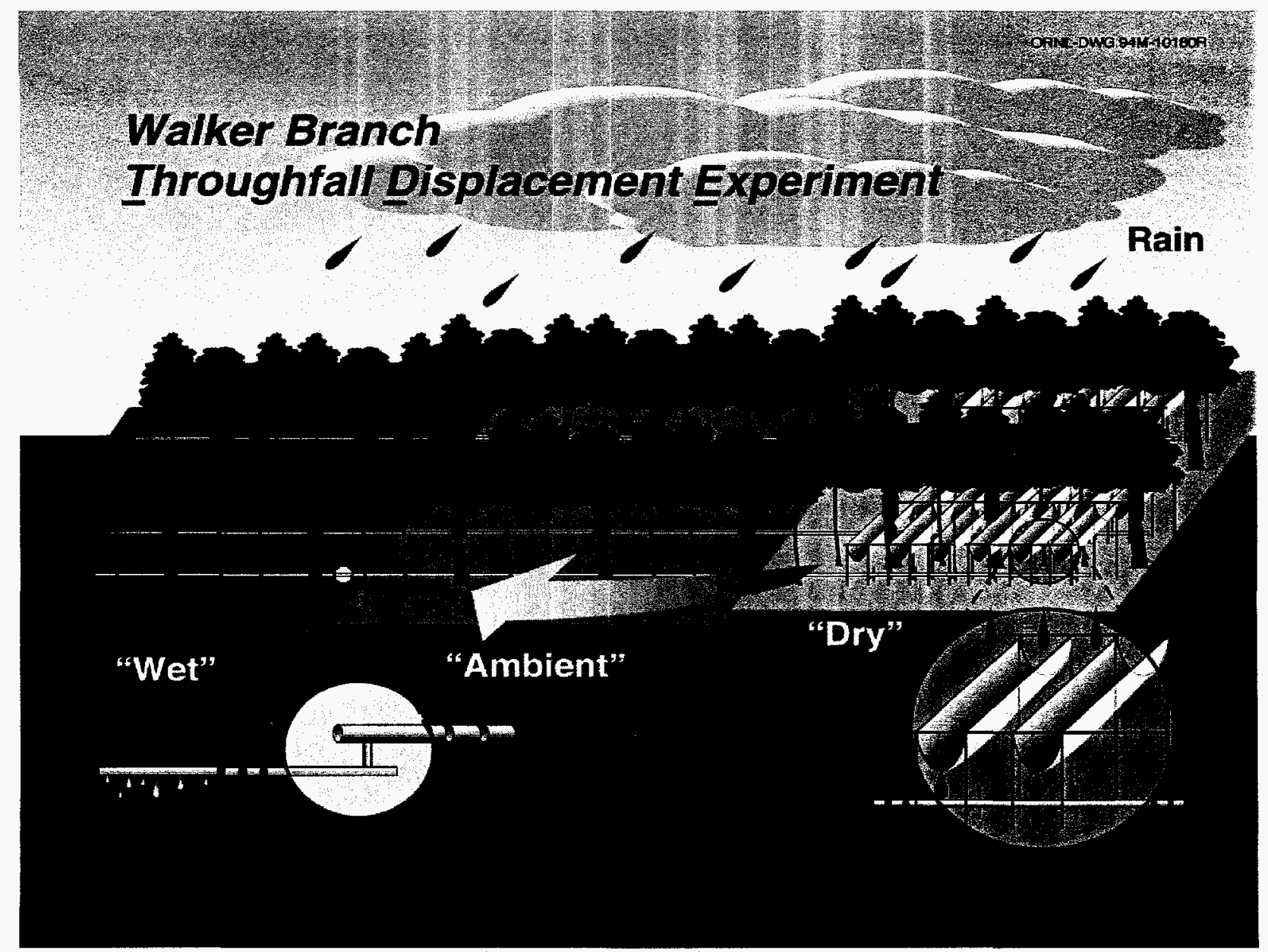

Fig. 1. Schematic diagram of the trough and piping network responsible for transporting $\approx 33 \%$ of total throughfall from the dry experimental plot across the ambient plot to distribution pipes extending the width of the wet plot. Each treatment plot was divided into an upper (rows 7-10), middle (rows 4-6), and lower (rows 1-3) slope position to account for elevational effects.

Paired lengths of iron concrete reinforcing bar $(12.5 \mathrm{~mm})$ of variable lengths were hammered vertically into the ground below the frost line, and short lengths of conduit were installed horizontally between the two pieces of reinforcing bar to form 'H-frames' on which the collection and distribution pipelines were supported and adjusted for appropriate drainage.

To ensure that mature trees of each plot had their canopies and root systems fully contained within a given soil water condition, the experimental plots were made as large as possible. Each treatment plot is 80 by $80 \mathrm{~m}$ (size was limited by the amount of uniform space available along the slope) and divided into 100 subplots that serve as the locations for repetitive, nondestructive measurements of soil and plant characteristics. Soil water content was chosen as the primary measurement for documenting ambient plot vs wet and dry treatment plot differences. Daily to weekly visual inspections of the trough and gutters and occasional measurements of the flow rates from each of the 20 pipelines were conducted to ensure uniform throughfall interception by the troughs.

The experimental design was not replicated because of cost and logistical limitations. Lack of replication forces a reliance on "pseudoreplication" (Eberhardt and Thomas 1991). Addressing pseudoreplication in our sampling design is critical (Hurlbert 1984). Eberhardt and Thomas (1991) recommend that unreplicated experiments be supported by adequate sampling of site environmental parameters (including climatic conditions), comparable ambient areas, and pretreatment sampling of key 
variables. To provide information for those variables, the site topography, soils, soil water patterns, microclimate, and vegetation were extensively characterized before setting up the throughfall displacement system. Although not without limitations, unreplicated experimental designs have been used to provide invaluable understanding of forest ecosystem processes in large-scale manipulative studies at the watershed scale. Classic examples are the Hubbard Brook (Borman and Likens 1979) and Coweeta watershed studies (Swank and Crossley 1988).

\subsection{VEGETATION CHARACTERISTICS}

Prior to beginning the experiment, all individual plants greater than $0.1 \mathrm{~m}$ in diameter at $1.3 \mathrm{~m}$ (diameter at breast height; dbh) were identified by species ( 729 individual trees), and tree heights and canopy widths were measured directly or derived from allometric relationships. An aerial view of the distribution of these species across the TDE is shown in Fig. 2. In addition, a side view of the vertical position of each species in the canopy is shown by slope position in Fig. 3. Figures 2 and 3 show the dominance of Quercus sp. with Acer sp. as a key co-dominant. Liriodendron tulipifera L. occurs as a canopy dominant on the lower slope positions, and Nyssa sylvatica Marsh. and Oxydendrum arboreum [L.] D.C. are predominant species occupying mid-canopy locations. Stand basal area averaged $21 \mathrm{~m}^{2} \mathrm{ha}^{-1}$ across the TDE, with nearly identical basal area on each treatment plot (Table 3 ). The number of saplings (trees $<0.1 \mathrm{~m} \mathrm{dbh}$ ) across the TDE area averages $3073 \mathrm{ha}^{-1}$ and contributes an additional $3.3 \mathrm{~m}^{2} \mathrm{ha}^{-1}$ to total stand basal area (Table 4). Acer rubrum L. and Cornus florida L. make up 59\% of all saplings and $48 \%$ of the sapling basal area.

\subsection{SOIL WATER MEASUREMENTS}

The percentage soil water content was measured with a time domain reflectometer (TDR; Soil Moisture Equipment Corp., Santa Barbara, California) following the procedure of Topp and Davis (1985) as documented for soils with high coarse fraction content (Drungil et al. 1987). To verify that TDR would yield soil water content data consistent with past data based on gravimetric observations on Walker Branch (Peters et al. 1970), we conducted cross comparison tests in 1993. The linear relationship, shown in Fig. 4 with a slope near 1, indicates general agreement between TDR-based soil water content measurements and gravimetric measurements of soil water content. Variability around this curve results from the coarse fraction of our soils (10 to $20 \%$ ) and the paired but not identical placement of the TDR probes and the destructive samples used for gravimetric water content determinations.

Sampling locations for TDR measurements were laid out in an $8 \times 8 \mathrm{~m}$ grid across the TDE for a total of 310 sampling locations. Two pairs of TDR waveguides were installed at each of the grid intersections. Each pair was positioned vertically from the surface. The shallow pair extended from the surface to $0.35 \mathrm{~m}$, and the deep pair extended from the surface to $0.7 \mathrm{~m}$. The shallow depth (i.e., 0 to $0.35 \mathrm{~m}$ ) corresponded to the zone of maximum root density on our site (Wolfe et al. 1997), and the $0.7 \mathrm{~m}$ depth neared the recommended maximum length for our TDR. Shallow soil water measurements in the 0 - to $0.15-\mathrm{m}$ depth were initially collected. However, they were discontinued because permanent 0 - to $0.15-\mathrm{m}$ rod installations were too susceptible to damage by random foot traffic. Point-in-time measurements with a single set of $0.15-\mathrm{m}$ rods attached to the waveguide connector were possible only for wet soils. Installation of horizontal buriable probes was not pursued in order to minimize disturbance to the forest floor. 

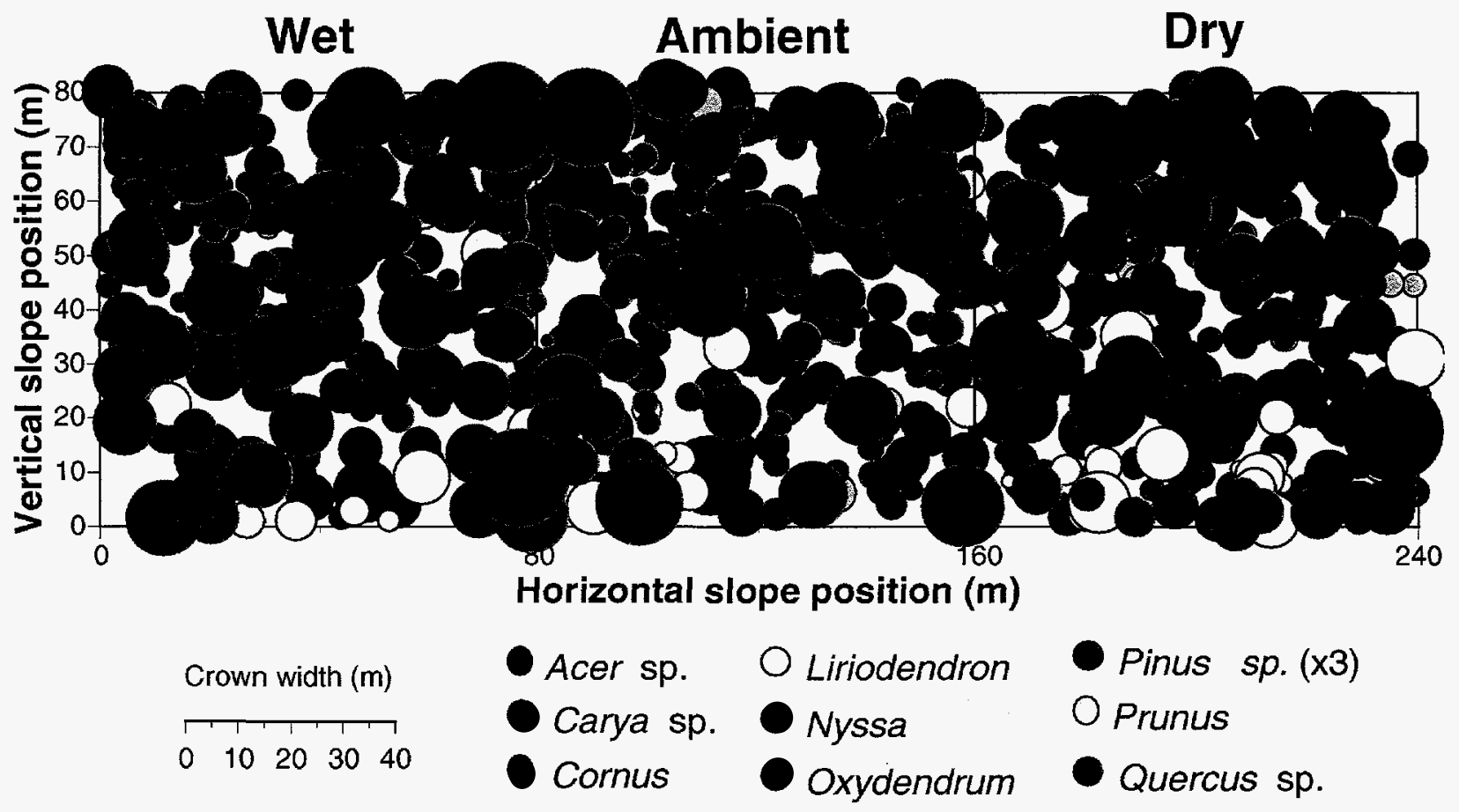

Fig. 2. An aerial view of the horizontal species distribution of all trees greater than $0.1 \mathrm{~m}$ in diameter at dbh across the Throughfall Displacement Experiment as of 1996. Circle size represents the canopy width of each tree. Top of the figure represents the top of the slope. 


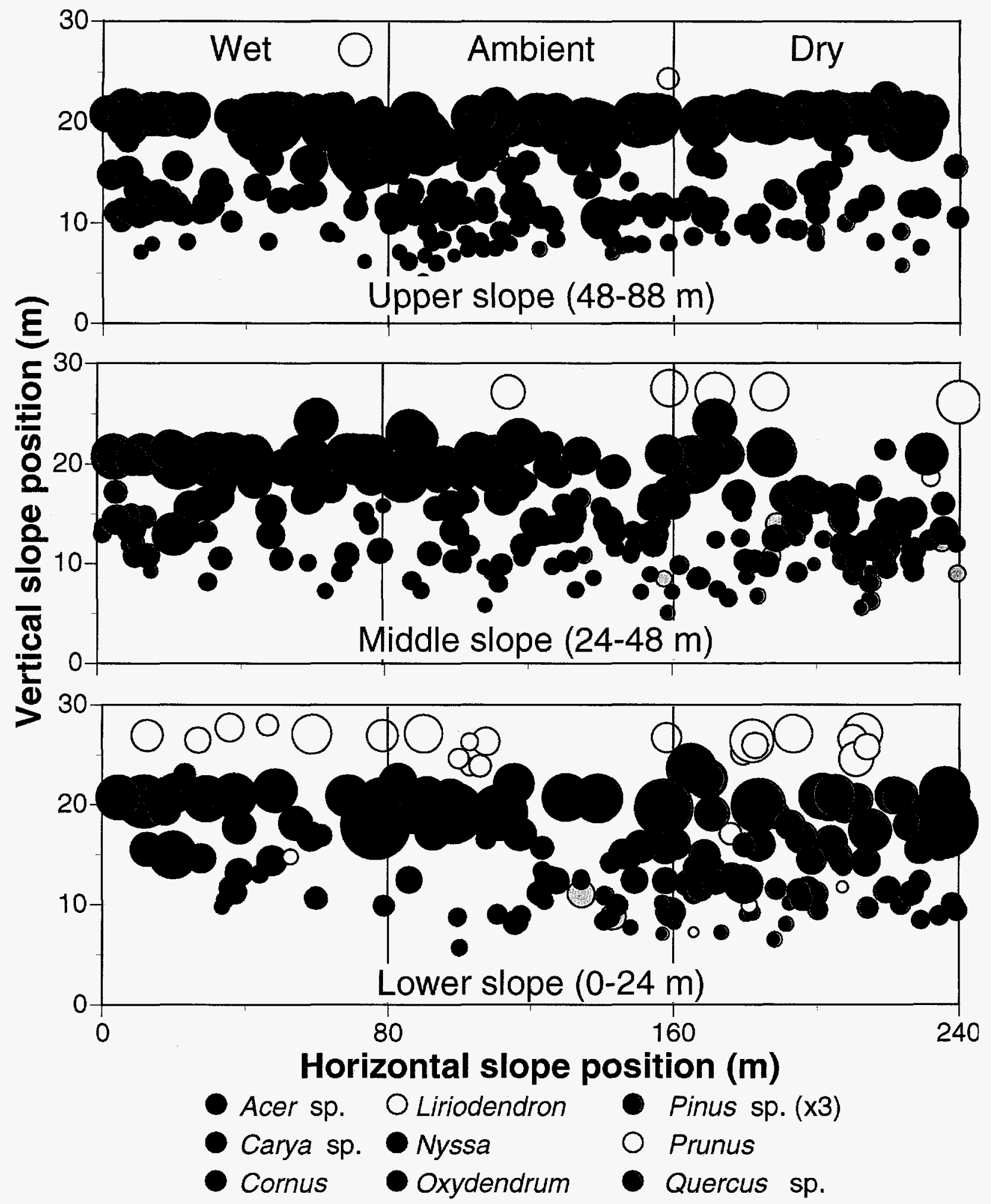

Fig. 3. A side view of the vertical position of individual tree crowns for (A) upper, (B) middle, and (C) lower slope positions across the Throughfall Displacement Experiment. Circle size represents the canopy width of each tree. Because this figure is based on trees greater than $0.1 \mathrm{~m} \mathrm{dbh}$ few crowns are shown below a height of $\sim 6 \mathrm{~m}$. 
Table 3. Cumulative basal area of individual tree species $>0.1 \mathrm{~m}$ dbh on each plot of the Throughfall Displacement Experiment site as of March 1994

\begin{tabular}{lcccc}
\hline \multirow{2}{*}{ Species $^{a}$} & \multicolumn{4}{c}{ Cumulative basal area by plot $\left(\mathrm{m}^{2} \mathrm{ha}^{-1}\right)$} \\
\cline { 2 - 5 } & Wet & Ambient & Dry & Total \\
\hline Acer rubrum L. & 2.4 & 2.3 & 2.5 & 2.4 \\
Acer saccharum Marsh. & 0.4 & 1.0 & 0.3 & 0.6 \\
Carya sp. & 0.6 & 0.3 & 0.4 & 0.4 \\
Conifers (Pinus, Juniperus) & 0.0 & 0.3 & 0.1 & 0.1 \\
Cornus florida L. & 0.0 & 0.2 & 0.3 & 0.2 \\
Liriodendron tulipifera L. & 1.3 & 1.4 & 2.3 & 1.6 \\
Nyssa sylvatica Marsh. & 1.9 & 3.8 & 2.9 & 2.9 \\
Oxydendrum arboreum [L.] D.C. & 0.6 & 1.0 & 1.0 & 0.9 \\
Prunus serotina Ehrh. & 0.1 & 0.1 & 0.1 & 0.1 \\
Quercus alba L. & 6.5 & 4.9 & 1.9 & 4.4 \\
Quercus prinus L. & 5.6 & 3.3 & 7.7 & 5.5 \\
Quercus sp. & 2.1 & 1.4 & 1.7 & 1.8 \\
\cline { 2 - 5 } Total by plot & 21.6 & 20.1 & 21.2 & 21.0 \\
\hline
\end{tabular}

${ }^{a} \mathrm{~A}$ total of 18 individual tree species were present in the $>0.1-\mathrm{m}$-dbh size range, but some species groups were combined for presentations in the table. 
Table 4. Number of individuals and cumulative basal area of each sapling species $<0.1 \mathrm{~m}$ dbh on each plot of the Throughfall Displacement Experiment site

\begin{tabular}{|c|c|c|c|c|}
\hline \multirow{2}{*}{ Species } & \multicolumn{4}{|c|}{ Cumulative Basal area by plot $\left(\mathrm{m}^{2} \mathrm{ha}^{-1}\right)$} \\
\hline & Wet & Ambient & Dry & Total \\
\hline & \multicolumn{4}{|c|}{ Number of saplings ha $a^{-1}$} \\
\hline Acer rubrum $\mathrm{L}$. & 1649 & 1215 & 1181 & 1348 \\
\hline Acer saccharum Marsh. & 0 & 87 & 17 & 35 \\
\hline Carya sp. & 191 & 104 & 87 & 127 \\
\hline Cornus florida $\mathrm{L}$. & 174 & 764 & 434 & 457 \\
\hline Fagus grandifolia J. F. Ehrh. & 69 & 104 & 69 & 81 \\
\hline Nyssa sylvatica Marsh. & 0 & 365 & 122 & 162 \\
\hline Oxydendrum arboreum [L.] D.C. & 69 & 122 & 122 & 104 \\
\hline Prunus serotina Ehrh. & 35 & 0 & 191 & 75 \\
\hline Quercus sp. & 139 & 243 & 208 & 197 \\
\hline Quercus alba $\mathrm{L}$. & 35 & 35 & 0 & 23 \\
\hline Quercus prinus $\mathbf{L}$. & 52 & 0 & 0 & 17 \\
\hline Rhamnus sp. & 0 & 0 & 174 & 58 \\
\hline Sassafras albidum (Nutt.) Nees & 17 & 69 & 17 & 35 \\
\hline Miscellaneous & 469 & 504 & 87 & 353 \\
\hline \multirow[t]{2}{*}{ Total } & $\overline{2899}$ & $\overline{3611}$ & $\overline{2708}$ & $\overline{3073}$ \\
\hline & \multicolumn{4}{|c|}{ Cumulative sapling basal area by species and plot $\left(m^{2} h a^{-1}\right)$} \\
\hline Acer rubrum $\mathrm{L}$. & 1.34 & 0.70 & 0.90 & 0.98 \\
\hline Acer saccharum Marsh. & 0.00 & 0.02 & 0.10 & 0.06 \\
\hline Carya sp. & 0.03 & 0.05 & 0.01 & 0.03 \\
\hline Cornus florida $\mathrm{L}$. & 0.27 & 0.81 & 0.78 & 0.62 \\
\hline Fagus grandifolia J. F. Ehrh. & 0.03 & 0.04 & 0.03 & 0.03 \\
\hline Nyssa sylvatica Marsh. & 0.00 & 0.68 & 0.26 & 0.47 \\
\hline Oxydendrum arboreum [L.] D.C. & 0.33 & 0.21 & 0.24 & 0.26 \\
\hline Prunus serotina Ehrh. & 0.01 & 0.00 & 0.30 & 0.15 \\
\hline Quercus sp. & 0.16 & 0.22 & 0.10 & 0.16 \\
\hline Quercus alba $\mathrm{L}$. & 0.01 & 0.12 & 0.00 & 0.07 \\
\hline Quercus prinus $\mathrm{L}$. & 0.03 & 0.00 & 0.00 & 0.00 \\
\hline Rhamnus sp. & 0.00 & 0.00 & 0.22 & 0.22 \\
\hline Sassafras albidum (Nutt.) Nees & 0.03 & 0.14 & 0.01 & 0.06 \\
\hline Miscellaneous & 0.28 & 0.34 & 0.09 & 0.24 \\
\hline Total & 2.51 & 3.31 & 3.05 & 3.35 \\
\hline
\end{tabular}




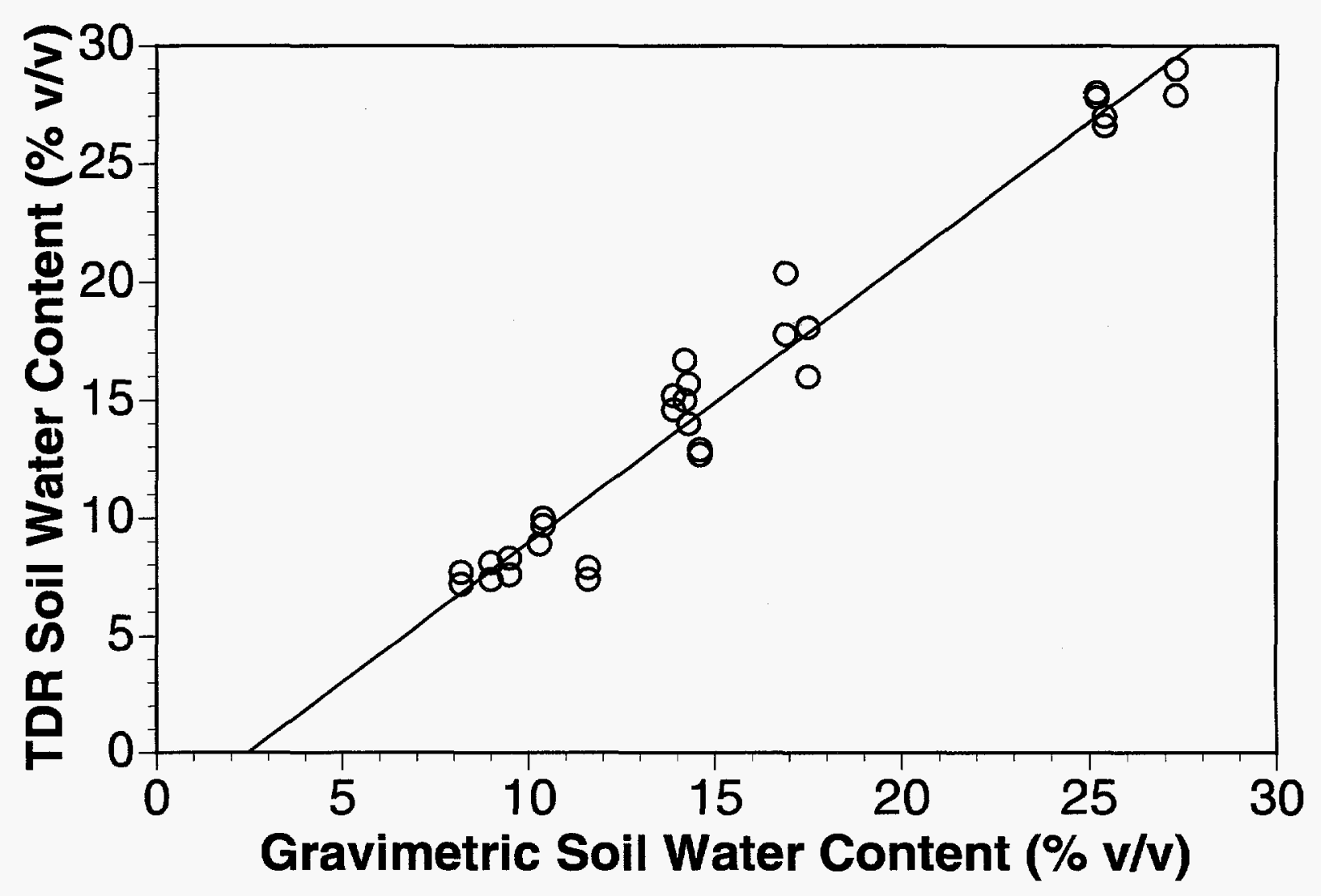

Fig. 4. Comparison of soil water content ( $v / v)$ obtained by means of time domain reflectometer and gravimetric approaches corrected for bulk density.

TDR waveguide installation was initiated in March 1992, but the complete complement of rods was not fully in place until August 12, 1992 (day 225). With all TDR rods installed, measurements of the water content across all sites were initiated ( 620 observations per measurement date). Soil water measurements were conducted biweekly during the growing season and monthly for dormant periods. Multiple TDR machines were required to accomplish the 620 observations on each measurement date ( 2 work days). On any given date, all measurements at a specific depth were made with the same machine. Intermachine comparisons conducted since 1992 indicate good agreement between TDR machines (data not shown).

Because the integrated measurement of the percent soil water in the 0 - to $0.7-\mathrm{m}$ depth interval (SW70) contains all of the soil water measured by the 0 - to $0.35-\mathrm{m}$ waveguides (SW35), the percent soil water content in the 0.35 - to $0.7-\mathrm{m}$ portion of the profile (SW3570) can be estimated by subtraction from the following equation:

$$
\mathrm{SW}_{3570}=\frac{\left[\left(\mathrm{SW}_{70} * 0.7 \mathrm{~m}^{3}\right)-\left(\mathrm{SW}_{35} * 0.35 \mathrm{~m}^{3}\right)\right]}{0.35 \mathrm{~m}^{3}}
$$

where 0.7 and $0.35 \mathrm{~m}^{3}$ are the total and partial volumes of a hypothetical soil sample $1 \times 1 \times(0.7$ or $0.35) \mathrm{m}$. 


\subsection{SOIL WATER POTENTIAL ESTIMATES}

Soil moisture retention curves were evaluated for representative A, AE, and EB horizon soils collected adjacent to the TDE site using psychrometric measurements of soil water potential and gravimetric measurements of soil water content (Fig. 5). Thermocouple psychrometers (SC-10, Decagon Devices, Inc., Pullman, Washington), calibrated before each use with a graded series of $\mathrm{NaCl}$ solutions, and nanovoltmeter thermometers (NT-3, Decagon Devices) were used to derive $\mu \mathrm{V}$ and temperature readings for conversion into water potential values.

The AE soil retention curve was assumed to be applicable to the 0 - to $0.35-\mathrm{m}$ soil depth increment, and that the EB soil retention curve was assumed appropriate for the $0.35-$ to $0.7-\mathrm{m} \mathrm{depth}$. These assumptions are of course subject to some error because of variations in the thickness of soil horizons across the TDE. To convert raw volumetric water content data (TDR $)$ collected on the TDE site-to-soilwater potential in $\mathrm{MPa}, \mathrm{TDR}_{\mathrm{T}}$ must first be corrected to account for the mean coarse fraction of the soil in question (Table 5). The appropriate calculation is as follows:

$$
\mathrm{TDR}_{\mathrm{c}}=\frac{\mathrm{TDR}_{\mathrm{r}}}{\left(\frac{100}{\mathrm{C}_{\mathrm{f}}}\right)} * 100,
$$

where $C_{f}$ is the appropriate mean coarse fraction for the TDE location of interest. Subsequent to this correction, $\mathrm{TDR}_{\mathrm{c}}$ is used as an input to the equations in Fig. 5 to yield soil water potentials for the depth increment.

\subsection{WEATHER CONDITIONS}

Incoming rainfall, irradiance (Pyranometer sensor, LiCor Inc., Lincoln, Nebraska), photosynthetic photon flux density (Quantum sensor, LiCor, Inc.), air temperature, and relative humidity (Model MP-100 Rotronics Instrument Corporation, Huntington, New York) were measured continuously and logged as hourly means at a clearing close to the TDE site as a surrogate for "above-canopy" inputs. Understory climate data, including photosynthetically active radiation (PAR) at $1.5 \mathrm{~m}$, air temperature, soil temperatures $(0.1$ and $0.35 \mathrm{~m})$, and relative humidity, were also logged hourly on each treatment plot. Throughfall quantity on each experimental plot is also being monitored with two tipping bucket rain gauges with $\approx 3$-m extension troughs attached. Air and soil temperature sensors (LiCor, Inc., Lincoln, Nebraska) used with the data loggers (LI-1000, LiCor, Inc., Lincoln, Nebraska) are thermistors set to read over a -10 to $50^{\circ} \mathrm{C}$ range.

To better judge the impact of the dry plot troughs on understory microclimates, additional litter and soil temperature measurements were conducted periodically from 1994 through 1996 . These observations were conducted on four transects ( 1 upslope, 2 midslope, 1 downslope) across the treatment plots ( 31 observations per transect). Transect observations were made during the growing and dormant seasons to determine if the TDE infrastructure had a microclimatic effect that differed with the extent of leaf-out or canopy closure. Soil temperatures were collected with a penetrating thermocouple capable of recording to the nearest $\pm 0.1^{\circ} \mathrm{C}$ (Model 450 -AET Omega Engineering Inc., Stamford, Connecticut). Forest floor litter surface temperatures were measured with an infrared thermometer (Everest Scientific, Inc., Fullerton, California), with the emissivity set to 0.98 . 


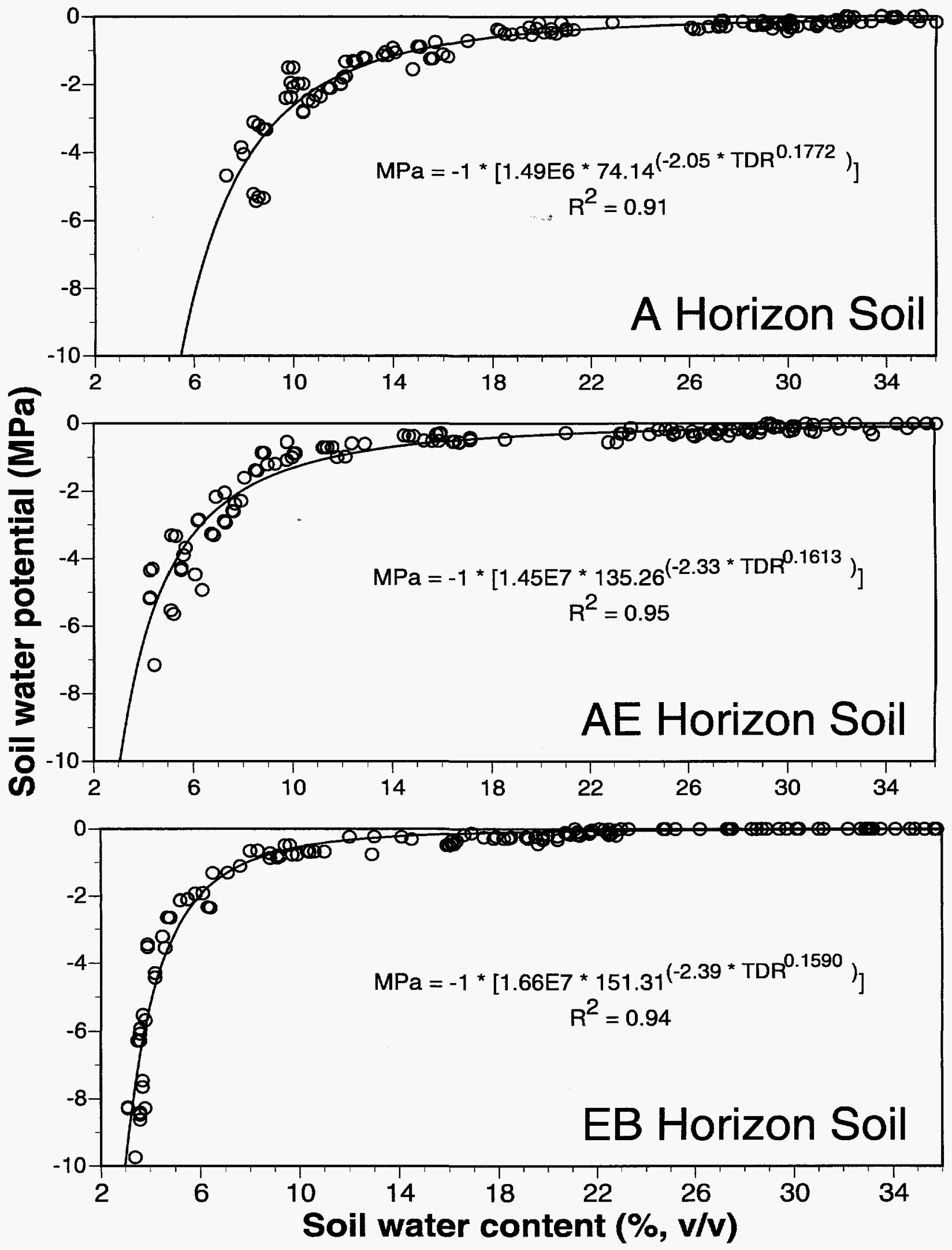

Fig. 5. Soil moisture release curves for representative A, AE, and EB horizon soils of the Throughfall Displacement Experiment. The fitted curves were generated with nonlinear least squares approaches. 
Table 5. Coarse fraction volume percent by position and depth increment on the Throughfall Displacement Experiment (TDE) site ${ }^{a}$

\begin{tabular}{lcc}
\hline \multirow{2}{*}{ TDE position } & \multicolumn{2}{c}{ Coarse fraction (\%) by depth } \\
\cline { 2 - 3 } & $0-0.3 \mathrm{~m}$ & $0.3-0.6 \mathrm{~m}$ \\
\hline Wet plot & 13.1 & 17.0 \\
Up & 14.4 & 17.1 \\
Middle & 12.5 & 18.1 \\
Lower & 11.5 & 15.1 \\
Ambient plot & 14.2 & 16.9 \\
Up & 15.9 & 17.3 \\
Middle & 13.0 & 16.6 \\
Lower & 12.7 & 16.2 \\
Dry plot & 15.3 & 17.2 \\
Up & 16.2 & 16.6 \\
Middle & 14.4 & 18.3 \\
Lower & 14.8 & 16.4 \\
TDE site mean & 14.2 & 17.0 \\
\hline
\end{tabular}

${ }^{a}$ Volume percent was determined from the average mass of rock material greater than $2-\mathrm{mm}$ diam sieved from ten $0.002432-\mathrm{m}^{3}$ cores of soil per TDE position. Average rock density was $2300 \mathrm{~kg} \mathrm{~m}^{-3}$.

\subsection{STATISTICAL APPROACH}

Pretreatment measurements (April 1992 through July 12, 1993) of soil water content and within-date analysis of variance for pretreatment horizontal and vertical slope positions across the TDE indicated the existence of pretreatment gradients in water content across the TDE area. There was a decreasing gradient of soil water from the lower to the upper slope positions, and the mean soil water content of the eastern third of the plot was lower than the rest. To effectively judge the effectiveness of the throughfall transfer system, these spatial patterns needed to be captured in a covariate matrix that could describe the influence of a specific slope position with respect to the overall site mean soil water content.

The pretreatment observations of the TDR grid network, measured from August 1992 through July 12,1993 , were used to generate this covariate matrix. The covariate matrix of values was determined from the experimental area's mean soil water content and its relationship to the grand mean for all locations: 


$$
\mathrm{Y}_{i j}=\sum\left(\mathrm{Y}_{i j k}\right) / n
$$

(in this study, $n=11$ ),

$$
\mathrm{Y}=\sum\left(Y_{i j}\right) / n
$$

(in this study, $n=310$ ),

$$
\operatorname{CovY}_{i j}=\left(Y_{i j}-Y\right) / s d Y
$$

where $Y_{i j}$ is the mean annual value for a given location, $Y$ is the grand mean for all locations and times, $i$ and $j$ are the horizontal and vertical coordinates of the TDE experimental area, $k$ is the month of the observation, and $n$ is the number of observations for a given summation. A contour plot of the covariate ranks for each of the measurement locations across the TDE is shown in part B of Fig. 6. Positive and negative values represent locations that exhibit greater or lesser water contents than the grand mean, respectively. Note that the overall tendency is for the dry treatment area to already be drier than the ambient and wet plots prior to beginning the experiment. Slope position, soil texture, and coarse fraction may contribute to the observed pretreatment tendencies across the TDE area. Although we hoped that a single covariate rank based on an entire year's worth of data would be robust enough to apply to all subsequent dates, we ended up generating two covariate ranks: one for the dormant season when soil water conditions are near saturation and one for summer periods. These covariate ranks are not substantially different than the overall ranks shown in Fig. 6.

Before the covariate analysis of variance could be used to test for significant treatment effects on soil water contents across the TDE, a lack of spatial autocorrelation among the individual rod pairs needed to be demonstrated. Semivariograms (Turner et al. 1991) based on TDR measurements of soil water content at a $0.15-\mathrm{m}$ spacing along both vertical and horizontal transects within the TDE area demonstrated that beyond 4 to $5 \mathrm{~m}$ the individual soil water measurements can be considered independent (data not shown). Therefore, having satisfied the need for independence of each measurement the individual soil water measurements at 8 by $8 \mathrm{~m}$ can be considered as true replicates. Covariate data sets were not available for litter and soil temperatures. A two-way analysis of variance was conducted to evaluate the impact of the trough and gutter infrastructure on understory microclimates. All statistical analyses were conducted with SPSS 6.1 for the Macintosh (SPSS, Inc., Chicago, Illinois). 


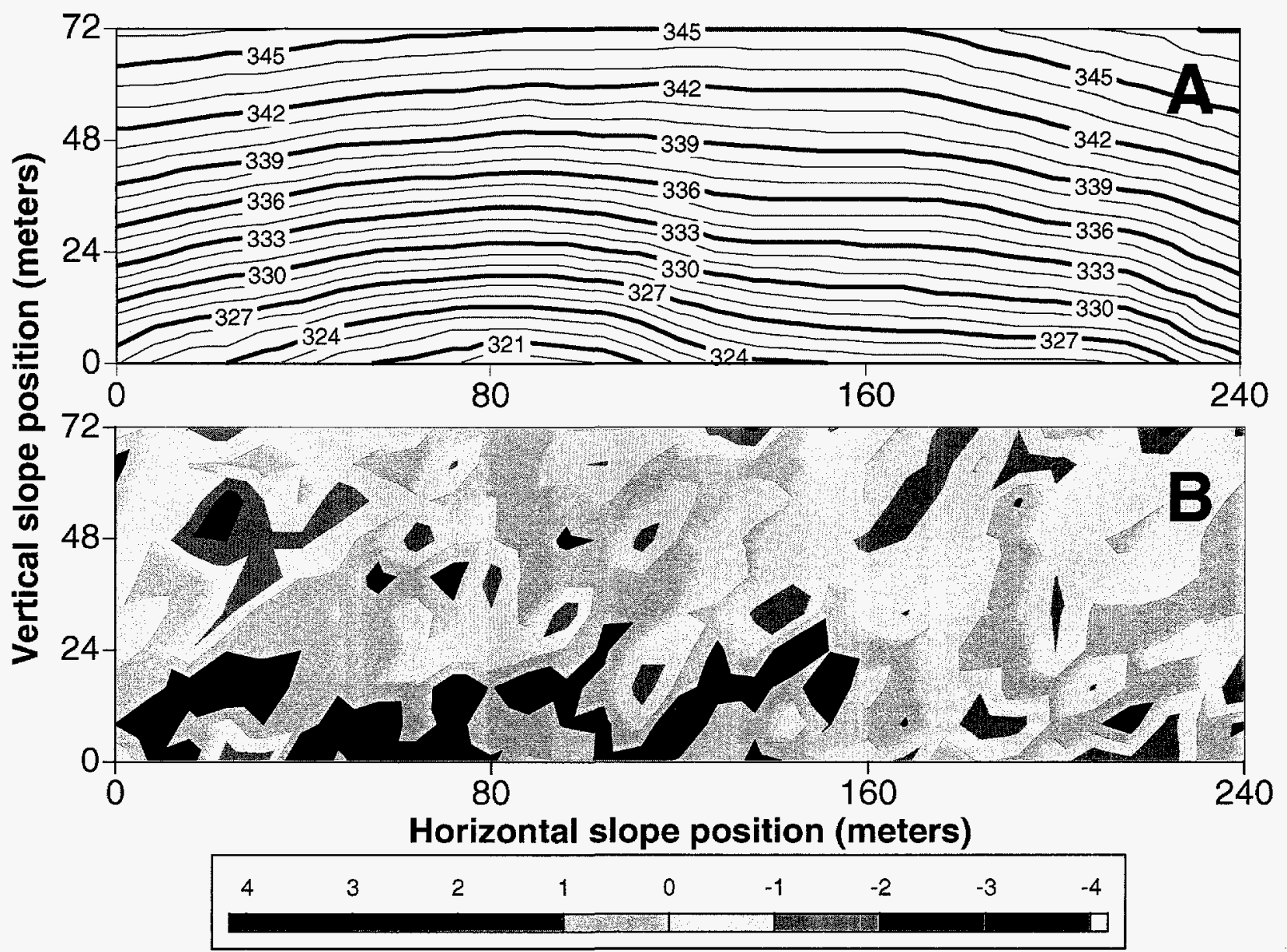

Fig. 6. (A) Elevation map of the experimental area in meters and (B) contour plot showing the pretreatment pattern of soil water across the experimental site expressed relative to the mean for the entire experimental area. A location with a rank of zero would be in agreement with the overall site mean. 



\section{TDE PERFORMANCE AND DISCUSSION}

\subsection{3-1996 WEATHER}

Climate and soil water measurements collected from 1992 through 1996 showed substantial variation in ambient precipitation conditions. The 1993 and 1995 seasons had $\sim 16 \%$ lower annual precipitation and 24 to $27 \%$ lower growing season rainfall than the long-term average for Walker Branch Watershed (Table 1). Conversely, 1994 and 1996 had 21 to $23 \%$ higher-than-average total annual precipitation. Growing season precipitation was near normal for 1994, but 47\% higher in 1996 (Table 1). Ambient temperatures and cumulative incident radiation were not as variable as precipitation from 1993 through 1996 (Table 2). The 1993 drought year had higher-than-average annual and growing season temperatures, and the wettest year (i.e., 1996) had the lowest mean annual temperature. Growing-season temperatures in 1994, 1995, and 1996 were nearer to normal (Table 2). Cumulative growing-season radiation inputs ranged from 2461 to $2830 \mathrm{MJ} \mathrm{m}^{-2}$ from 1992 through 1996 but showed no consistent trends with annual or growing-season precipitation. The variable interannual climate and precipitation regimes allowed us to conduct the TDE under conditions ranging from wet (1996) to dry (1993 and 1995). The closest year to the mean ambient year was 1994.

\subsection{TDE IMPACTS ON VOLUMETRIC WATER CONTENT}

The seasonal patterns of mean TDR soil water content by treatment in the 0 - to 0.35 - and 0.35 - to 0.7-m depth increments from 1993 through 1996 are shown in Fig. 7. Since the initiation of treatments in 1993, significant differences in the soil water content in the 0- to 0.35-m depth increment have been present, except during dormant seasons when all soils were at or near saturation, or at the depth of the drought in 1995 (See Appendix Tables A1 through A9). During a typical winter rain event on February 11,1994 , a subset of the 0 - to 0.35 -m rods were measured under saturated conditions and we found the soils of the wet plot to be significantly elevated above those of the ambient and dry treatment areas (data not shown). Calculated soil water contents for the $0.35-$ to $0.7-\mathrm{m}$ depth show a similar separation of treatment means, but the differences are not as great nor are they as sustained in any one season as those in the 0 - to 0.35 -m layer.

Contour plots of the 0 - to 0.35 -m soil water contents for selected dates in 1993, 1994, 1995, and 1996 are shown in Figs. 8 through 11, respectively. In each year of our study it is clear that we always begin the growing season with saturated soils. Subsequently, with the initiation of substantial evaporative demand and canopy transpiration in mid-to-late May the dry-plot water contents are drawn down faster than those in the ambient and wet plots. In the drought years of 1993 (Fig. 8) and 1995 (Fig. 10), long periods without rainfall cause treatment differentials to disappear. However, following the depth of droughts in 1993 and 1995 treatment differences redeveloped as the soils refilled. Substantial impacts on the dry-plot water budget were maintained well into November 1993 and 1994 (Figs. 8 and 9).

A decreasing gradient of soil water from the lower to the upper slope positions is evident across the TDE area. Lower slope positions typically maintain higher water contents caused by gravity drainage of water laterally through the soils (Mulholland 1993). The slope effect is not without exception. For example, some mid-slope locations have higher water contents than the lower-slope areas (e.g., midslope on the dry plot). Over the entire season it would appear that positional differences across the TDE site are maximal during dry periods and minimal in the dormant season when the system nears field capacity. The permanent site bias due to soil characteristics is captured in the covariate rankings described previously (Fig. 6). A careful comparison of the patterns of Fig. 6 and the soil water contour plots of Figs. 8 through 11 indicates the consistency of this pattern except under the driest conditions. 


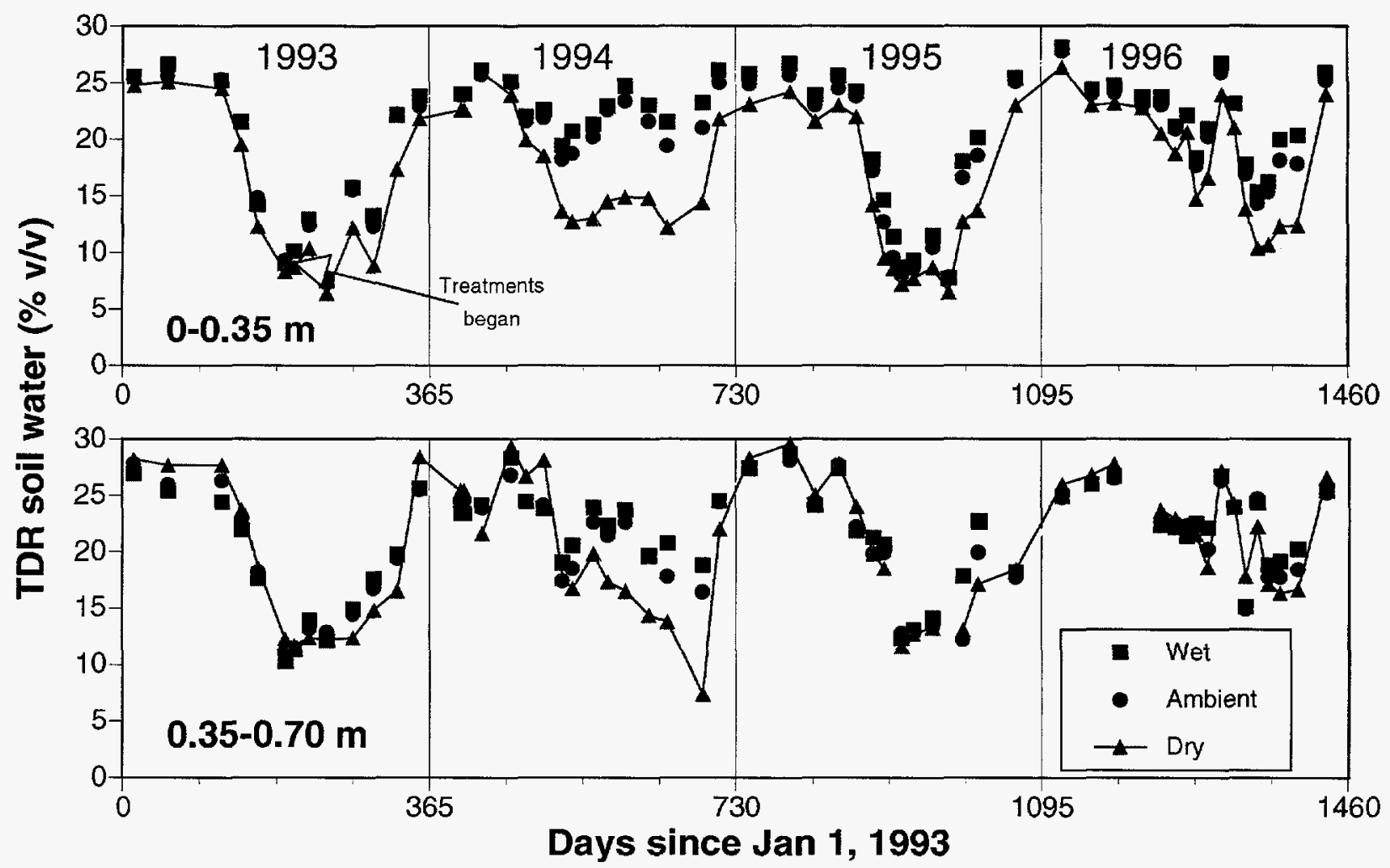

Fig. 7. The seasonal patterns of soil water content $(\% \mathrm{v} / \mathrm{v})$ from 1993 through 1996 for the $0-$ to $0.35-\mathrm{m}$ and the 0.35- to 0.7-m soil depths. Data are the mean values for the wet, ambient, and dry plots on the Walker Branch Throughfall Displacement Experiment. Throughfall displacement treatments were initiated on July 14, 1993 (see arrow at top left). 


\section{Pre-treatment}
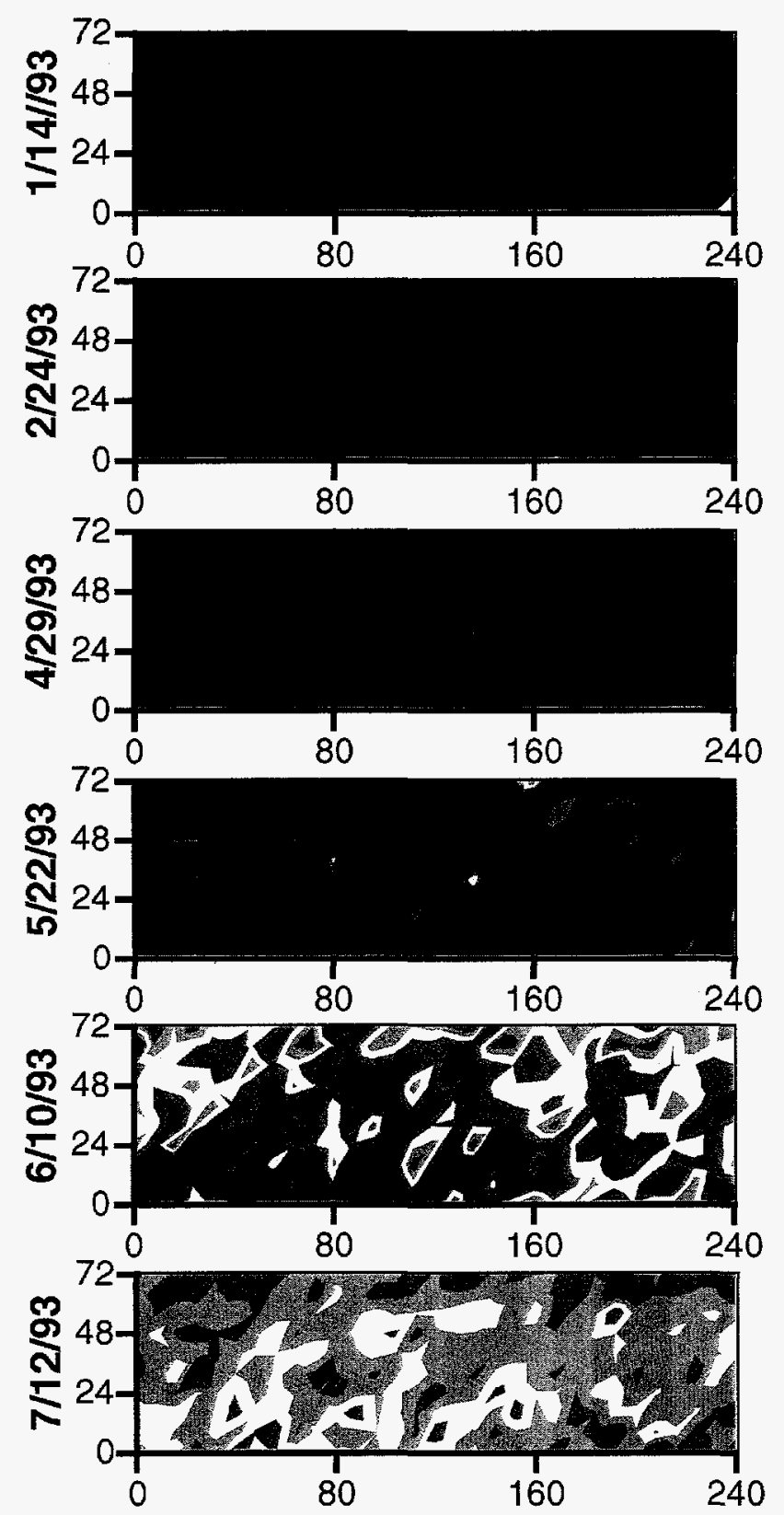

\section{Post- treatment}
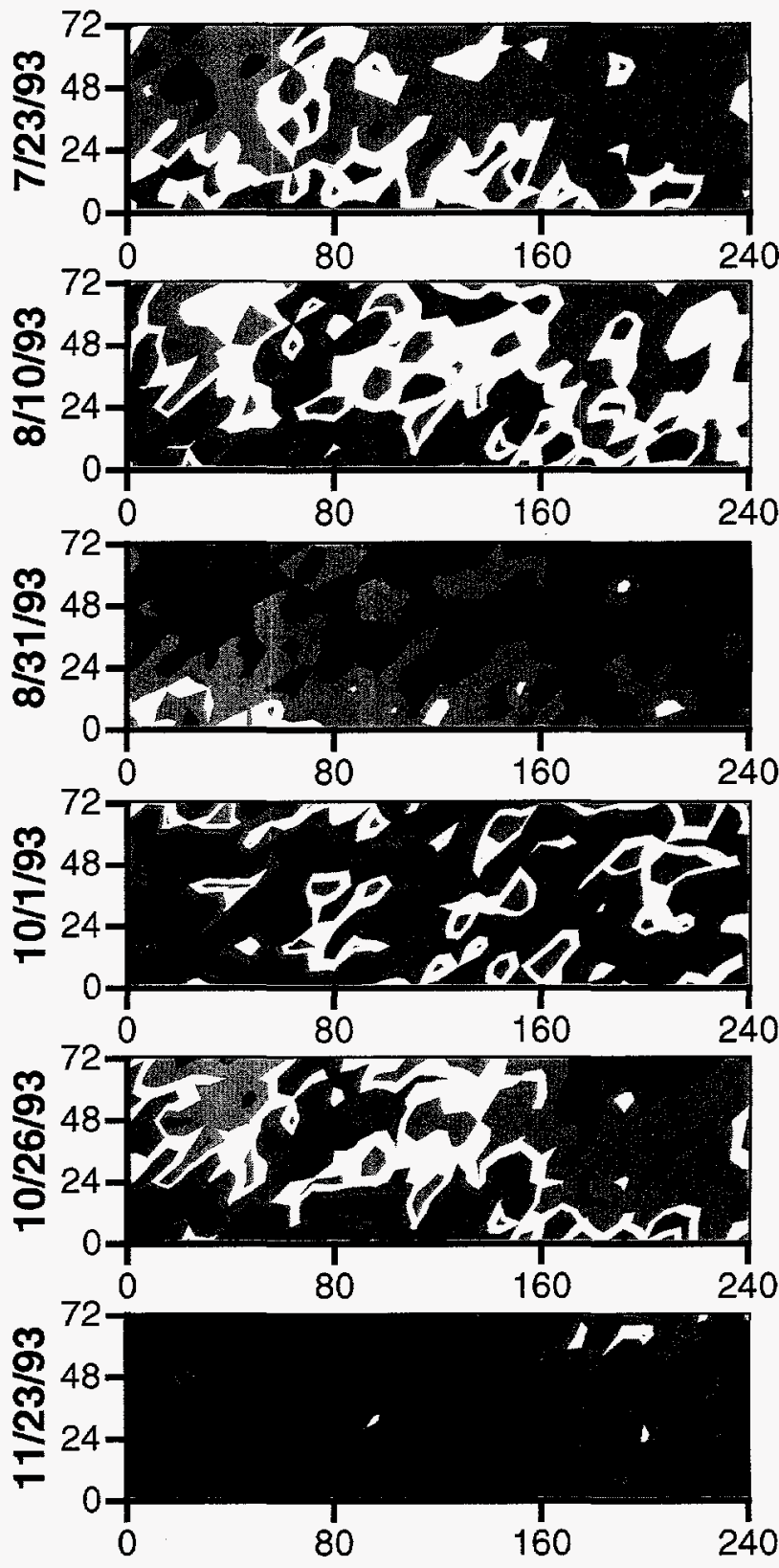

15

25

30

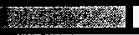

Soil water content $(\%, v / v)$

Fig. 8. Contour plots of the mean soil water content from 0 to $0.35 \mathrm{~m}$ across the Throughfall

Displacement Experiment area throughout 1993. Throughfall displacement was initiated between July 12 and July 23. Numbers along the $\mathrm{x}$ - and $\mathrm{y}$-axis of each plot are meters. 

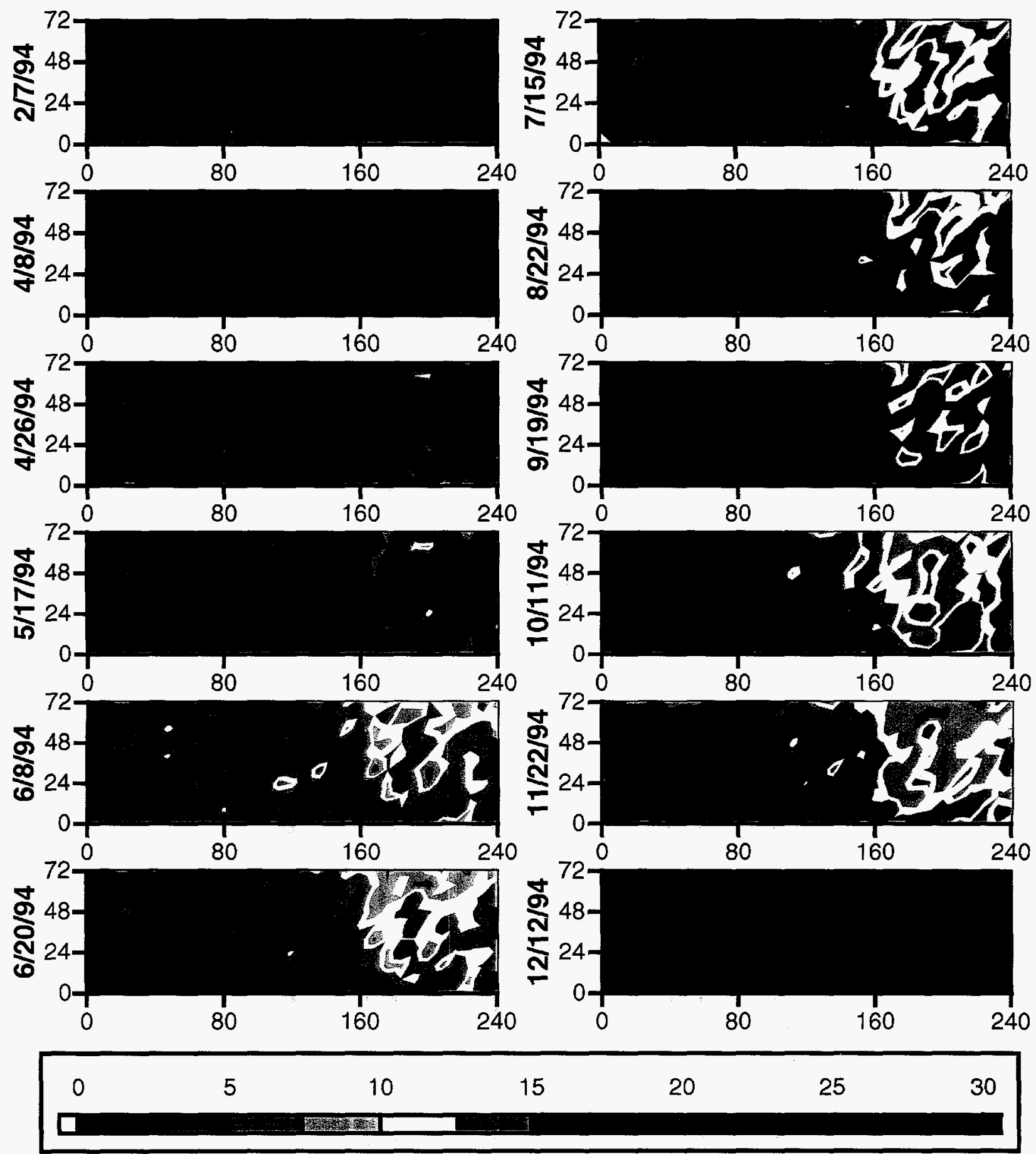

\section{Soil water content $(\%, v / v)$}

Fig. 9. Contour plots of the mean soil water content from 0 to $0.35 \mathrm{~m}$ across the Throughfall

Displacement Experiment area throughout 1994. March 4 and August 8 data were left off of this plot. Numbers along the $\mathrm{x}$ - and $\mathrm{y}$-axis of each plot are meters. 

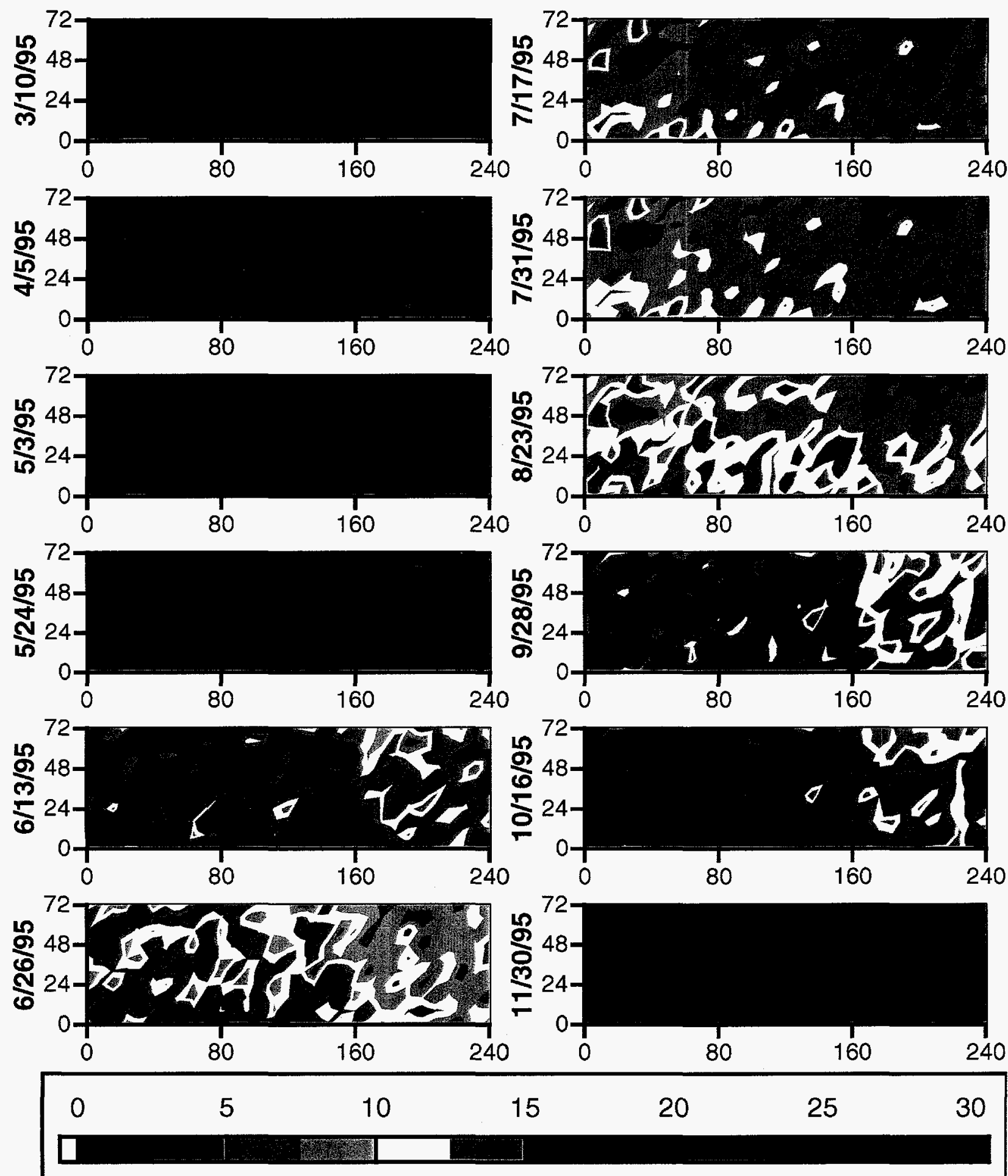

\section{Soil water content $(\%, v / v)$}

Fig. 10. Contour plots of the mean soil water content from 0 to $0.35 \mathrm{~m}$ across the Throughfall

Displacement Experiment area throughout 1995. The January 17 data were left off of the figure. Numbers along the $x$ - and $y$-axis of each plot are meters. 

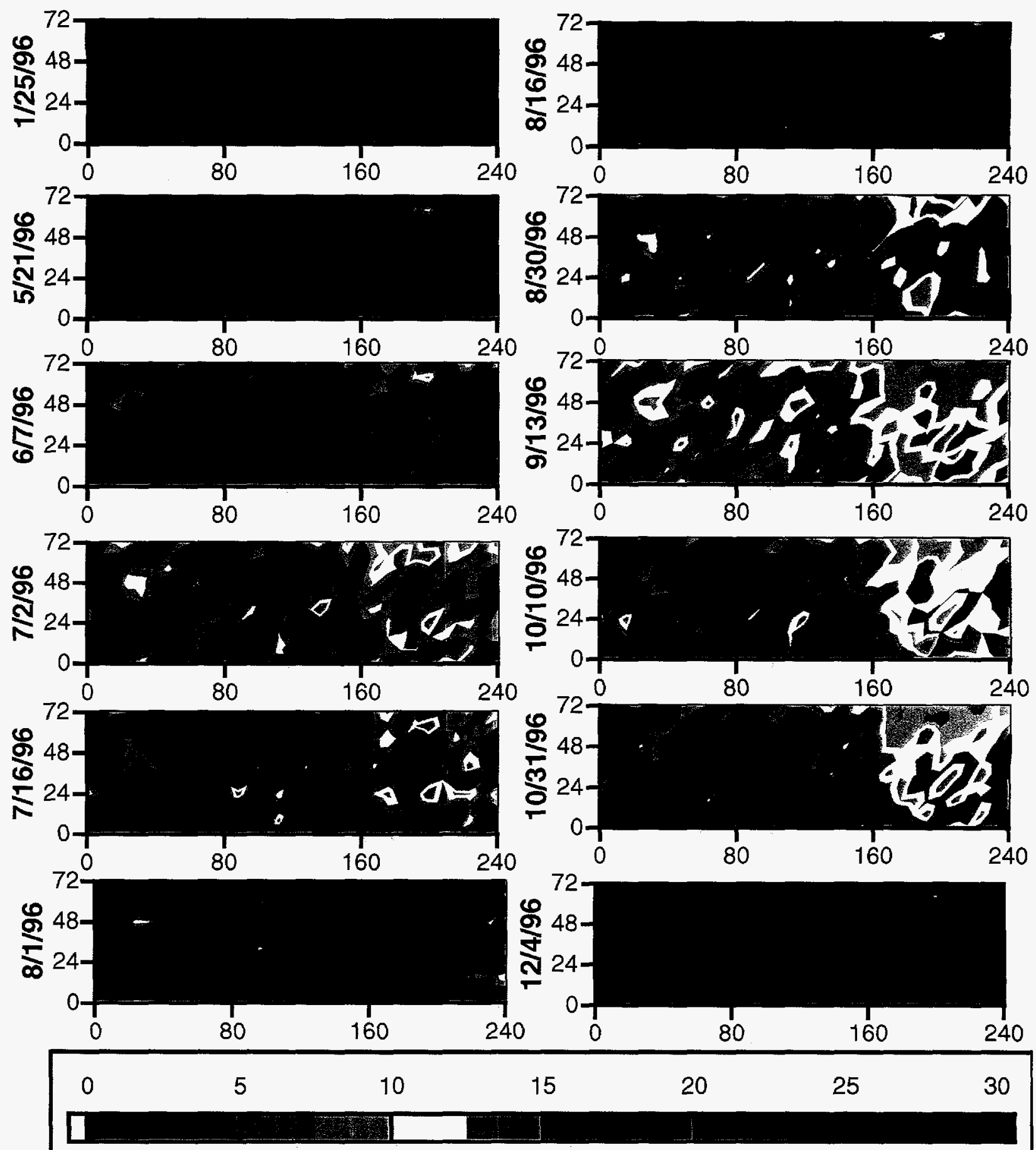

\section{Soil water content $(\%, v / v)$}

Fig. 11. Contour plots of the mean soil water content from 0 to $0.35 \mathrm{~m}$ across the Throughfall

Displacement Experiment area throughout 1996. February 29, March 27, and April 29 data were left off of this plot. Numbers along the $\mathrm{x}$ - and $\mathrm{y}$-axis of each plot are meters. 


\subsection{TDE IMPACTS ON SOIL WATER POTENTIAL}

For analysis of plant and/or soil responses to the TDE treatments we need to convert the soil water content data (Figs. 8-11; Tables A1-A9) to soil water potential as described previously. These estimates were broken out by treatment and slope position, yielding an upper-, middle-, and lower-slope position within each treatment. The upper-slope position includes transects 7 through 10 ; the middle, transects 4 through 6; and the lower, transects 1 through 3. The results of this process can be seen in Fig. 12 for the overall treatment means and depth increments. Individual treatment $\times$ slope soil water potentials are plotted for 1993-1996 in Fig. 13. Figures 12 and 13 emphasize the year-to-year differences in soil water status.

Even though soil water contents begin to decline with leaf-out in April and May, declining soil water potentials are not apparent for any year or treatment until after the beginning of June (i.e., after day 150). Another important distinction between the soil water content and soil water potential (Figs. 6 and 11) is the impression of the treatment effects on water in the $0.35-$ to $0.70-\mathrm{m}$ soil depth. Soil water content data in Fig. 6 and statistical analyses in Appendix A suggest significant differences in soil water content for these deep soils. However, when these data are converted and expressed in terms of soil water potentials (Figs. 11 and 12) these treatment differences are no longer prevalent. The lack of differences in soil water potential below $0.35 \mathrm{~m}$ is important; we deduce from it that biological changes observed in response to the TDE treatments are driven by changes in surface soil water status.

Although ambient throughfall inputs in the dry 1995 growing season were comparable to the reduced dry-plot precipitation inputs in 1994 (Table 1), the resultant ambient soil water potentials were quite different. Soil water potentials were -0.2 MPa or greater in 1994 and most of 1996, but they often fell below $-0.8 \mathrm{MPa}$ and reached minimums $>-1.0 \mathrm{MPa}$ in 1995 (Figs. 12 and 13). Furthermore, although drought periods of 1993 and 1995 reached similar minimum soil water potentials (albeit at different times of the year), the duration of each year spent at severe stress levels was different. To quantify this year-to-year difference, a revised version of the PROSPER model (Goldstein et al. 1974, Huff et al. 1977, Vose and Swank 1994) coded using "Ithink" modeling software (High Performance Systems, Hanover, New Hamshire) for Macintosh computer systems was used to integrate the ambient soil water budgets for each year of the study. Daily outputs from this calculation representing the upper ambient position of the TDE area are superimposed over the observed data in Fig. 13. Summing these daily values for each year yields a cumulative index of drought stress (MPa days) that is useful for interyear comparisons. The wet 1994 and 1996 growing seasons had cumulative water potential exposures of -25 and $-32 \mathrm{MPa}$ days, which is much less than the values of -71 and $-116 \mathrm{MPa}$ days for 1993 and 1995 . This index of water stress exposure duration clearly shows that 1995 was the most severe of the two drought years.

\subsection{ADEQUACY OF THE 80- BY 80-m PLOT SIZE}

The initial plot sizes were chosen based on the available space on the southeast slope making up the TDE area. However, we were concerned that the central trees of each plot be adequately away from the plot edges so that appropriate treatment conclusions could be drawn. Positioning the plots at the top of a ridge divide eliminated the concern over upslope incursion of water into the three TDE plots, and original plans left a $16-\mathrm{m}$ buffer between treatment plots $(8 \mathrm{~m}$ on the ends) in which no biological observations were made.

Figures 8-11 clearly show a sharp boundary between the ambient and dry plots of the TDE with little evidence of edge effects suggesting that our $16-\mathrm{m}$ buffer is adequate. Conversely, we did have initial problems with even distribution of water onto the wet plot in the fall of 1993 . The contour plots for August 10, October 1, and October 26 of 1993 all show an excess amount of water draining into the wet plot up and down the slope near the 80 -m horizontal position (i.e., just after entering the wet plot). This problem was corrected in late 1993 by re-leveling the distribution pipes. 


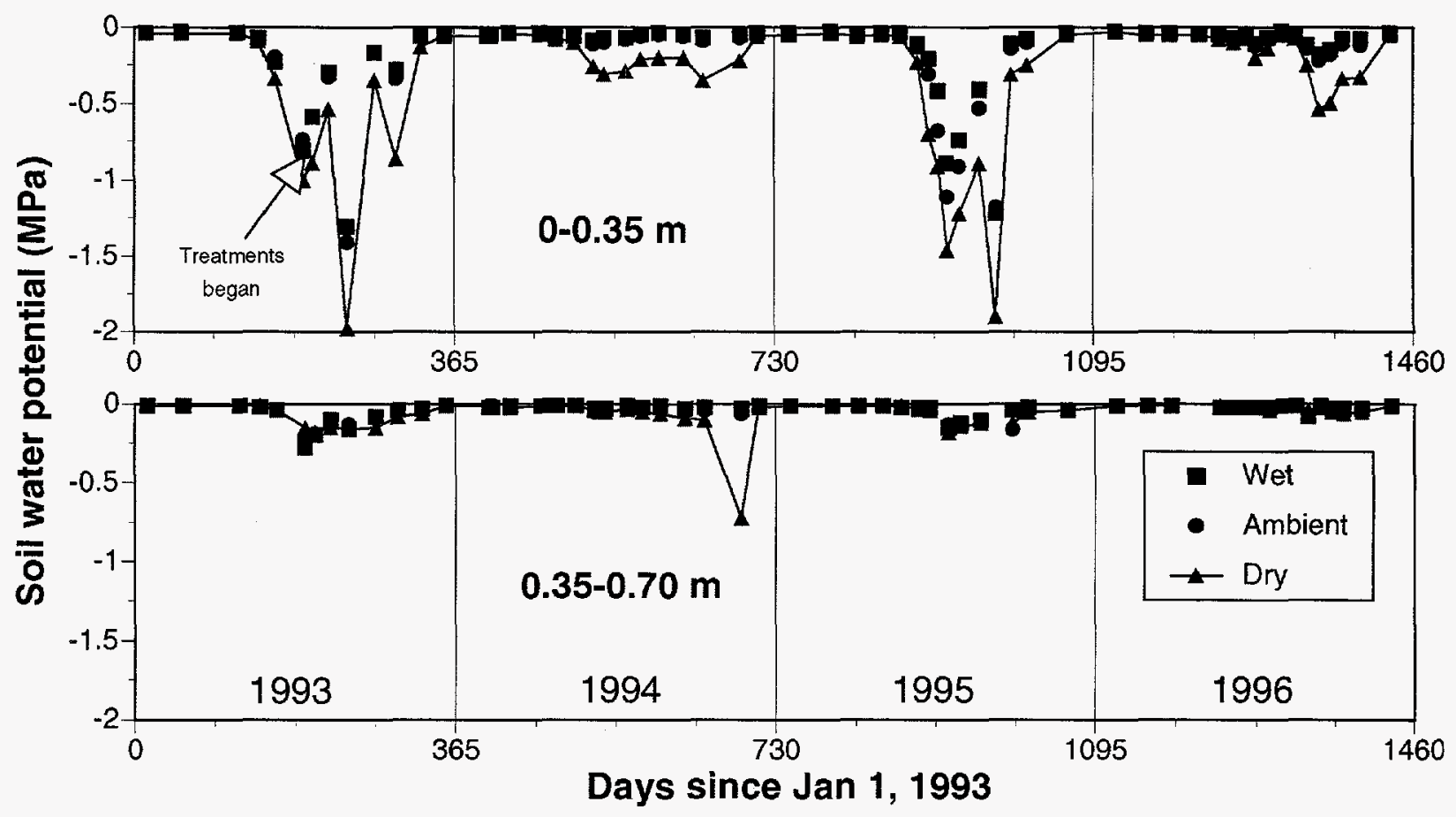

Fig. 12. Soil water potentials from 1993 through 1996 for the 0 - to $0.35-\mathrm{m}$ and the $0.35-$ to $0.7-\mathrm{m}$ soil depths. Data are the mean values for the wet, ambient, and dry plots on the Walker Branch Throughfall Displacement Experiment. Throughfall displacement treatments were initiated on July 14, 1993 (see arrow at top left). 


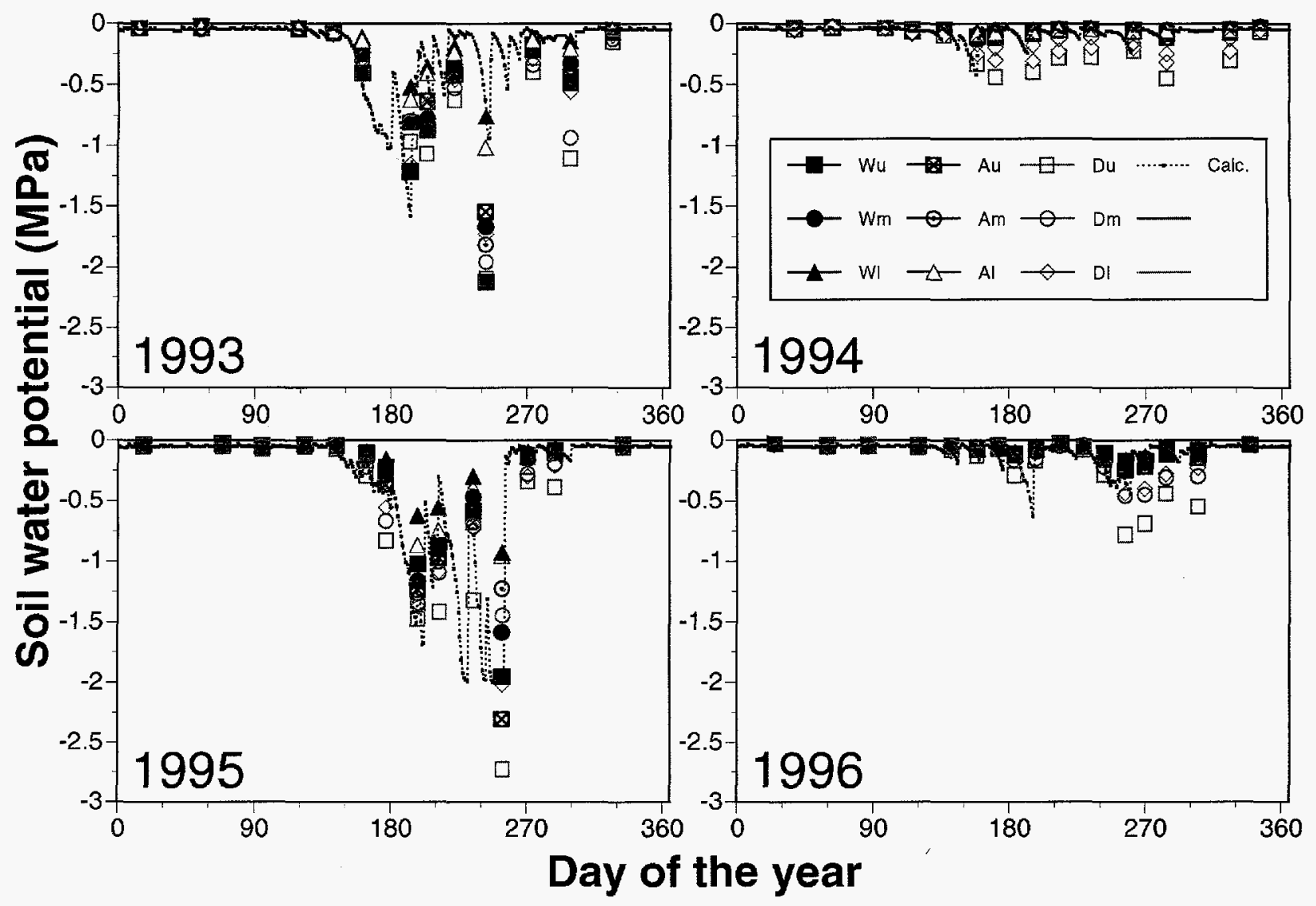

Fig. 13. Soil water potential for the 0 - to $0.35-\mathrm{m}$ depth for the nine treatment and slope positions of the Throughfall Displacement Experiment throughout 1993, 1994, 1995, and 1996. Soil water potentials were estimated from measured soil water contents and soil moisture release curves after correction for the coarse fraction of the soils. The wet, ambient, and dry plots are distinguished in the key (upper right) by uppercase W, A, and $\mathrm{D}$, respectively; lower case $1, \mathrm{~m}$, and $\mathrm{u}$ represent the lower, middle, and upper slope positions. The dashed line represents the calculated daily water potential for the ambient upper slope position.

Windthrown- and lightning-damaged trees on the upper-west corner of the wet plot in June 1995 (Hanson et al. 1997) allowed us to further evaluate the effective horizontal rooting volume for large canopy Quercus prinus L. and Quercus alba L. trees. A comparison of the $0-$ to $0.35-\mathrm{m}$ soil water contour plots for June 13, 1995, through September 28, 1995, show clear evidence of the impact of the loss of canopy on soil water in the dry plot. In particular, the July 17 and 31, 1995, plots show two wet zones in the upper-left corner of the wet plot, which correspond to the area in which the large tree canopies were removed. The maximum diameter for 'effective' rooting from any individual tree appeared to fall within a 16-m circle, with the damaged trunks near the center. Clearly, these trees may have had roots that were active beyond $8 \mathrm{~m}$ from the trunk of the tree, but the soil water patterns of Fig. 10 suggest that much of the influence of a given tree would fall within this distance from the trunk. Furthermore, because the trees were felled by wind one could argue that they had abnormally small root systems, and we might conservatively conclude that the effective rooting diameters suggested above are a minimum. 


\subsection{TDE TEMPERATURE AND CHEMICAL IMPACTS}

Any experimental design involves compromises between ideal conditions and logistical reality, and Gundersen (1995) discussed some of the common unintended implications of large-scale manipulation studies that include altered radiation regimes, temperatures, and chemical inputs. In addition to the TDE's intended impact on soil water content, we originally anticipated that the presence of the troughs, gutters, and pipes might act as a radiation barrier or thermal blanket during periods of incomplete canopy leaf coverage and lead to changes in the understory microclimate. Although the presence of the throughfall interception troughs on the dry plot clearly intercept some of the radiation that would typically reach the forest floor during the dormant season, we have observed no change in surface vegetation as a result. During the growing season when the canopy is fully leafed-out, the contribution of the troughs to any radiation is drastically reduced because of the low levels of radiation reaching trough heights. Observations of soil temperatures at $0.15 \mathrm{~m}$ and the temperature of the forest floor litter layer indicate no consistent significant trends with respect to TDE treatments, although soil and litter were occasionally warmer on the dry and ambient plots when compared with the wet treatment plot (Table 6). However, when significant warming of the dry-plots litter and soils was discovered, temperature differences seldom exceeded a few tenths of a degree. The small temperature increases under the troughs were calculated to increase soil respiration by $\sim 1 \%$ if present throughout the year. However, since temperature differences occur only periodically it is not likely that significant sustained impacts on litter/soil decomposition and root activity are occurring. We have no evidence of any temperature differences at night.

Table 6. Mean litter surface and soil $(0.15 \mathrm{~m})$ temperatures $\left({ }^{\circ} \mathrm{C}\right)$ for each treatment area of the Walker Branch Throughfall Displacement Experiment on selected dates. Significant treatment differences are indicated by $p$-values $<0.05$

\begin{tabular}{|c|c|c|c|c|c|c|c|}
\hline \multirow{2}{*}{$\begin{array}{c}\text { Variable } \\
2 / 1 / 94\end{array}$} & \multicolumn{3}{|c|}{ Dormant season } & \multicolumn{3}{|c|}{ Growing season } & \multirow{2}{*}{ Treatment } \\
\hline & $2 / 1 / 95$ & $4 / 17 / 94$ & $4 / 25 / 94$ & $6 / 29 / 95$ & $7 / 1 / 94$ & $10 / 1 / 96$ & \\
\hline \multicolumn{8}{|c|}{ Litter surface } \\
\hline Wet & 4.2 & 15.6 & - & - & 25.3 & 24.4 & 17.3 \\
\hline Ambient & 5.9 & 16.4 & - & - & 24.9 & 23.4 & 19.6 \\
\hline Dry & 5.9 & 15.8 & - & - & 26.3 & 23.3 & 19.8 \\
\hline$p$-value & $<0.01$ & 0.40 & - & - & $<0.01$ & $<0.01$ & 0.95 \\
\hline \multicolumn{8}{|c|}{$0.15-m$ soil } \\
\hline Wet & 6.5 & 4.3 & 9.2 & 14.6 & 19.5 & 18.9 & 16.4 \\
\hline Ambient & 6.5 & 4.1 & 9.2 & 14.6 & 19.5 & 18.8 & 16.4 \\
\hline Dry & 6.6 & 4.9 & 9.5 & 14.7 & 19.6 & 18.8 & 16.7 \\
\hline$p$-value & 0.15 & $<0.01$ & $<0.01$ & 0.12 & 0.06 & 0.67 & $<0.01$ \\
\hline
\end{tabular}

Chemicals from atmospheric deposition and canopy leaching are transferred with the throughfall precipitation from the dry treatment plots to the wet treatment plots, thus introducing another variable to the experiment in addition to the water manipulation. However, these chemical inputs appear to be small in comparison with the annual demand placed on the forest soils by the growing vegetation (Cole and Rapp 1981). The influence of the TDE on nutrient cycling processes in forest stands is discussed in Johnson et al. (1998). 


\subsection{COST OF IMPLEMENTING THE TDE}

The TDE was constructed at an approximate initial cost of $\$ 300,000$ (U.S. dollars). The dollar value is based on 1993 U.S. dollars. This initial capital outlay plus maintenance and quality assurance activities, which cost approximately $\$ 50,000$ (U.S. dollars) per year from 1994 through 1996, yields a total cost of $\$ 450,000$ (U.S. dollars) for three full years of operation. This three-year cost works out to be just under \$37 U.S. dollars per square meter of ground measured, or \$2030 (U.S. dollars) per mature dominant tree. We believe that this is a cost-effective method for large-scale forest manipulations. 


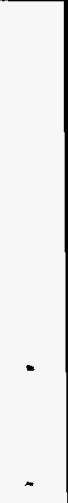




\section{CONCLUSIONS}

The TDE design was developed to address questions related to sustained changes in forest ecosystem processes to a fractional change in precipitation inputs anticipated to coincide with global warming. Extreme scenarios, such as the $100 \%$ throughfall removal, were considered unsuitable for application in the eastern United States. Reductions in soil moisture anticipated from the TDE manipulation of -33\% of the throughfall was anticipated to be comparable with the driest growing season of the 1980s drought (Cook et al. 1988), which was reported to have resulted in sapling mortality and reduced growth of some vegetation (Jones et al. 1993). Notwithstanding our avoidance of a $100 \%$ removal treatment, shorter-term (1- to 2-month) periods of $100 \%$ removal, simulating rare seasonal droughts, may be a justifiable scenario (Beier et al. 1995). The importance of seasonal drying sequences are discussed further in the companion to this paper (Hanson et al. 1997).

The TDE has operated continuously since treatments were initiated in July 1993 and throughout 1996. During this period, soil water measurements have shown that the TDE can produce significantly different hydrologic budgets for the wet, ambient, and dry plots in years having both high and low growing-season precipitation. Additionally, because of the substantial inter-annual variability in growing-season rainfall inputs we have obtained a much broader range of treatments than originally anticipated. The 1993 and 1995 growing seasons were exceptionally dry compared with the wet seasons in 1994 and 1996 (Fig. 13). This combined variability in annual and growing-season rainfall (Table 1) has allowed us to test not only the impact of a constant $\pm 33 \%$ alteration of throughfall resulting from all incoming rainfall events, but to determine the influence of sustained severe droughts as well. Furthermore, the experimental design is able to produce these differences without significant confounding impacts on the understory microclimate. 


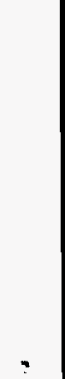




\section{REFERENCES}

Beier, C., P. Gundersen, K. Hansen, and L. Rasmussen. 1995. Experimental manipulations of water and nutrient input to a Norway spruce plantation at Klosterhede, Denmark II. Effects on tree growth and nutrition. Plant Soil 168-69:613-22.

Bormann, F. H., and G. E. Likens. 1979. Pattern and Process in a Forested Ecosystem: Disturbance, Development, and the Steady State Based on the Hubbard Brook Ecosystem Study. Springer-Verlag, New York.

Cole, D. W., and M. Rapp. 1981. Elemental cycling in forest ecosystems. pp. 341-409. In D. E. Reichle (ed.), Dynamic Principles of Forest Ecosystems. Cambridge University Press, London.

Cook, E. R., M. A. Kablack, and G. C. Jacoby. 1988. The 1986 drought in the southeastern United States: How rare an event was it? J. Geophys. Res. 93(D11):14257-60.

Cooter, E .J., B. K. Eder, S. K. LeDuc, and L. Truppi. 1993. General circulation model output for forest climate change research and applications. Gen. Tech. Rep. SE-85. U.S. Department of Agriculture, Forest Service, Southeastern Forest Experiment Station. Asheville, N.C.

Cregg, B. M., J. E. Halpin, P. M. Dougherty, and R. O. Teskey. 1989. Comparative physiology and morphology of seedling and mature forest trees. pp. 111-18. In R. D. Noble, J. L. Martin, and K. F. Jensen (eds.), Air Pollution Effects on Vegetation Including Forest Ecosystems. United States Department of Agriculture, Washington, D.C.

Davis, M. B. 1989. Lags in vegetation response to greenhouse warming. Clim. Change 15:75-82.

Dougherty, P. M., and T. M. Hinckley. 1981. The influence of a severe drought on net photosynthesis of white oak (Quercus alba). Can. J. Bot. 59:335-341.

Drungil, C. E. C., T. J. Gish, and K. Abt. 1987. Soil moisture determination in gravelly soils with time domain reflectometry. Paper No. 87-2568. American Society of Agricultural Engineers, St. Joseph, Mich.

Eberhardt, L. L., and J. M. Thomas. 1991. Designing environmental field studies. Ecol. Monogr. 61:53-73.

Ellsworth, D. S., and P. B. Reich. 1992. Water relations and gas exchange of Acer saccharum seedlings in contrasting natural light and water regimes. Tree Physiol. 10:1-20.

Epron, D., E. Dreyer, and N. Breda. 1992. Photosynthesis of oak trees [Quercus petraea (Matt.) Liebl.] during drought under field conditions: diurnal course of net $\mathrm{CO}_{2}$ assimilation and photochemical efficiency of photosystem II. Plant Cell Environ. 15:809-820.

Ginter-Whitehouse, D. L., T. M. Hinckley, and S. G. Pallardy. 1983. Spatial and temporal aspects of water relations of three tree species with different vascular anatomy. For. Sci. 29:317-329.

Goldstein, R. A., J. B. Mankin, and R. J. Luxmoore. 1974. Documentation of PROSPER-A model of atmosphere-soil-plant water flow. EDFB-IBP 73-9, UC-48. Oak Ridge National Laboratory. 
Graham, R. L., M. G. Turner, and V. H. Dale. 1990. How increasing $\mathrm{CO}_{2}$ and climate change affect forests. BioScience 40:575-87.

Gundersen, P. 1995. Unintended differences between natural and manipulated forest plots. pp. 335-43. In A. Jenkins, R. C. Ferrier, and C. Kirby (eds.), Ecosystem Manipulation Experiments: Scientific Approaches, Experimental Design and Relevant Results, Ecosystem Research Report No. 20, Commission of the European Communities, Luxembourg.

Hanson, P. J., D. E. Todd, N. T. Edwards, and M. A. Huston. 1995. Field performance of the Walker Branch Throughfall Displacement Experiment. pp. 307-13. In A. Jenkins, R. C. Ferrier, and C. Kirby, (eds.), Ecosystem Manipulation Experiments: Scientific Approaches, Experimental Design and Relevant Results, Ecosystem Research Report No. 20, Commission of the European Communities, Luxembourg.

Hinckley, T. M., J. P. Lassoie, and S. W. Running. 1978. Temporal and spatial variations in the water status of forest trees. For. Sci. Monogr. 20:1-72.

Houghton, J. T., L. G. Meira-Filho, B. A. Callander, N. Harris, A. Kattenberg, and K. Maskell (eds.). 1996. Climate Change 1995: The Science of Climate Change. Cambridge University Press, New York.

Huff, D. D., R. J. Luxmoore, J. B. Mankin, and C. L. Begovich. 1977. TEHM: a terrestrial ecosystem hydrology model. EDFB/IBP-76/8, ORNL/NSF/EATC-27. Oak Ridge National Laboratory.

Hurlbert, S. H. 1984. Pseudoreplication and the design of ecological field experiments. Ecol. Monogr. 54:187-211.

Johnson, D. W., and R. I. VanHook (eds.). 1989. Analysis of Biogeochemical Cycling Processes in Walker Branch Watershed. Springer-Verlag, New York.

Johnson, D. W., P. J. Hanson, D. E. Todd, Jr., R. B. Susfalk, and C. F. Trettin. 1998. Precipitation change and soil leaching: field results and simulations from Walker Branch Watershed, Tennessee. Water Air Soil Pollut. (in press).

Jones, E. A., D. D. Reed, G. D. Mroz, H. O. Liechty, and P. J. Cattelino. 1993. Climate stress as a precursor to forest decline: paper birch in northern Michigan, 1985-1990. Can. J. For. Res. 23:229-33.

Kattenberg, A., F. Giorgi, H. Grassl, G. A. Meehl, J. F. B. Mitchell, R. J. Stouffer, T. Tokioka, A. J. Weaver, and T. M. L.Wigley. 1996. Climate models-projections of future climate. pp. 283-357. In J. T. Houghton et al. (eds.), Climate Change 1995: The Science of Climate Change. Cambridge University Press, New York.

Kirschbaum, M. U. F., and A. Fischlin. 1996. Climate change impacts on forests. pp. 95-129. In R. T. Watson, M. C. Zinyowera, and R. H. Moss (eds.), Climate Change 1995: Impacts, Adaptations, and Mitigation of Climate Change: Scientific-Technical Analysis. Cambridge University Press, New York.

Kliener, K. W., M. D. Abrams, and J. C. Schultz. 1992. The impact of water and nutrient deficiencies on the growth, gas exchange and water relations of red oak and chestnut oak. Tree Physiol. 11:271-87. 
Kolb, T. E., K. C. Steiner, L. H. McCormick, and T. W. Bowersox. 1990. Growth response of northern red-oak and yellow-poplar seedlings to light, soil moisture and nutrients in relation to ecological strategy. For. Ecol. Manage. 38:65-78.

Melillo, J. M., T. V. Callaghan, F. I. Woodward, E. Salati, and S. K. Sinha. 1990. Effects on ecosystems. pp. 282-310. In J. T. Houghton, G. J. Jenkins, and J. J. Ephraums (eds.), Climate Change-The IPCC Scientific Assessment. Cambridge University Press, New York.

Mellilo, J. M., I. C. Prentice, G. D. Farquhar, E.-D. Schulze, and O.E. Sala. 1996. Terrestrial biotic responses to environmental change and feedbacks to climate. pp. 445-81. In J. T. Houghton et al. (eds.), Climate Change 1995: The Science of Climate Change. Cambridge University Press, New York.

Mohnen, V. A., and W.-C. Wang. 1992. An overview of global warming. Environ. Toxicol. Chem. 11:1051-59.

Mooney, H. 1991. Biological response to climate change: an agenda for research. Ecol. Appl. 1:112-17.

Mooney, H. A., B. G. Drake, R. J. Luxmoore, W. C. Oechel, and L. F. Pitelka. 1991. Predicting ecosystem responses to elevated $\mathrm{CO}_{2}$ concentrations. BioScience 41:96-104.

Mulholland, P. J. 1993. Hydrometric and stream chemistry evidence of three storm flowpaths in Walker Branch Watershed. J. Hydrol. 151:291-316.

Neilson, R. P., G. A. King, R. L. DeVelice, J. Lenihan, D. Marks, J. Dolph, B. Campbell, and G. Glick. 1989. Sensitivity of ecological landscapes and regions to global climatic change. U.S. Environmental Protection Agency, Environmental Research Laboratory, Corvallis, Oreg.

Overpeck, J. T., P. J. Bartlein, and T. Webb. 1991. Potential magnitude of future vegetation change in eastern North America: comparisons with the past. Science 254:692-95.

Pastor, J., and W. M. Post. 1988. Response of northern forests to $\mathrm{CO}_{2}$-induced climate change. Nature 334:55-58.

Peters, L. N., D. F. Grigal, J. W. Curlin, and W. J. Selvidge. 1970. Walker Branch Watershed Project: chemical, physical and morphological properties of the soils of Walker Branch Watershed. ORNLTM-2968. Oak Ridge National Laboratory.

Pezeshki, S. R., and J. L. Chambers. 1986. Stomatal and photosynthetic response of drought-stressed cherrybark oak (Quercus falcata var. pagodaefolia) and sweet gum (Liquidambar styraciflua). Can. J. For. Res. 16:841-846.

Ragsdale, H. L., S. E. Lindberg, G. M. Lovett, and D. A. Schaefer. 1992. Atmospheric deposition and throughfall fluxes of base cations. pp. 235-53. In D. W. Johnson and S. E. Lindberg (eds.), Atmospheric Deposition and Nutrient Cycling. Springer-Verlag, New York.

Rind, D., R. Goldberg, J. Hansen, C. Rosenzweig, and R. Ruedy. 1990. Potential evapotranspiration and the likelihood of future drought. J. Geophys. Res. 95(D7):9983-10004. 
Rind, D., C. Rosenzweig, and R. Goldberg. 1992. Modelling the hydrologic cycle in assessments of climate change. Nature 358:119-22.

Schneider, S. H. 1989. The greenhouse effect: science and policy. Science 243:771-81.

Smith, J. B., and D. A. Tirpak (eds.). 1989. The potential effects of global climate change on the United States. U.S. Environmental Protection Agency, Hemisphere Publishing Corp., Washington, D.C.

Swank, W. T., and D. A. Crossley Jr., (eds.). 1988. Forest Hydrology and Ecology at Coweeta. SpringerVerlag, New York.

Solomon, A. M. 1986. Transient response of forests to $\mathrm{CO}_{2}$-induced climate change: Simulation modeling experiments in eastern North America. Oecologia 68:567-79.

Topp, G. C., and J. L. Davis. 1985. Measurement of soil water content using time domain reflectometry (TDR): a field evaluation. Soil Sci. Soc. Am. J. 49:19-24.

Turner, S. J., R. V. O'Neill, W. Conley, M. R. Conley, and H. C. Humphries. 1991. Pattern and scale: Statistics for landscape ecology. pp. 17-49. In Quantitative Methods in Landscape Ecology: The Analysis and Interpretation of Landscape Heterogeneity. Springer-Verlag, New York.

Turner, R. S., P. J. Hanson, M. A. Huston, C. T. Garten Jr., and P. J. Mulholland. 1993. A large-scale throughfall manipulation experiment on Walker Branch Watershed, pp. 96-105. In L. Rasmussen, T. Brydges, and P. Mathy (eds.), Experimental Manipulations of Biota and Biogeochemical Cycling in Ecosystems, Ecosystem Research Report No. 4. Commission of the European Communities, Luxembourg.

Vose, J. M., and W. T. Swank. 1994. Effects of long-term drought on the hydrology and growth of a white pine plantation in the southern Appalachians. For. Ecol. Manage. 64:25-39.

Wigley, T. M. L., K. R. Briffa, and P. D. Jones. 1984. Predicting plant productivity and water resources. Nature 312:102-103.

Woodward, F. I. 1992. Tansley Review No. 41: Predicting plant responses to global environmental change. New Phytol. 122:239-51. 
APPENDIX 


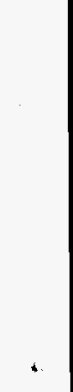


Table A1. 1992 pretreatment percent soil water content in the 0 - to $0.35-\mathrm{m}$, or the 0 - to $0.7-\mathrm{m}$ depth layer, categorized by treatment and slope position. Percentage of all rod pairs measured successfully on each date is indicated, and the $p$-value for pretreatment main effects of proposed treatment location, slope position, and their interaction are provided.

\begin{tabular}{|c|c|c|c|c|c|c|c|c|c|c|c|c|}
\hline \multirow[t]{2}{*}{ Pretreatment/slope } & \multicolumn{6}{|c|}{$\begin{array}{c}\text { Day of the year } \\
(0-\text { to } 0.35-\mathrm{m} \text { depth })\end{array}$} & \multicolumn{6}{|c|}{$\begin{array}{c}\text { Day of the year } \\
\text { (0- to } 0.7-\mathrm{m} \text { depth) }\end{array}$} \\
\hline & 192 & 225 & 253 & 283 & 323 & 349 & 192 & 225 & 253 & 283 & 323 & 349 \\
\hline & \multicolumn{12}{|c|}{ Measured values } \\
\hline \multicolumn{13}{|l|}{ Wet positions } \\
\hline Lower & 24.2 & 20.9 & 16.2 & 19.6 & 24.8 & 26.9 & 23.0 & 19.8 & 16.9 & 18.7 & 23.4 & 25.1 \\
\hline Middle & 22.6 & 15.8 & 10.3 & 14.1 & 22.2 & 24.8 & 22.4 & 16.6 & 13.1 & 14.2 & 23.4 & 23.9 \\
\hline Upper & 21.6 & 14.4 & 9.5 & 14.5 & 20.8 & 24.7 & 21.2 & 16.1 & 11.9 & 14.9 & 20.6 & 24.1 \\
\hline \multicolumn{13}{|l|}{ Ambient } \\
\hline Lower & 24.4 & 19.8 & 15.3 & 20.4 & 24.0 & 26.7 & 24.4 & 19.9 & 17.4 & 20.4 & 23.6 & 26.7 \\
\hline Middle & 20.5 & 17.8 & 12.0 & 17.3 & 22.5 & 25.4 & 23.0 & 19.5 & 15.4 & 17.9 & 25.1 & 25.4 \\
\hline Upper & 22.0 & 16.0 & 10.8 & 15.3 & 22.5 & 25.0 & 21.1 & 17.3 & 12.6 & 16.3 & 23.6 & 25.0 \\
\hline \multicolumn{13}{|l|}{ Dry positions } \\
\hline Lower & 20.7 & 15.0 & 11.0 & 15.0 & 20.8 & 24.2 & 23.2 & 19.2 & 15.3 & 17.0 & 24.8 & 24.2 \\
\hline Middle & 21.0 & 15.4 & 9.9 & 15.5 & 22.3 & 25.8 & 24.0 & 17.1 & 13.1 & 16.6 & 26.0 & 25.8 \\
\hline \multirow[t]{2}{*}{ Upper } & 19.6 & 12.7 & 8.7 & 13.4 & 21.5 & 24.1 & 21.2 & 15.2 & 11.1 & 15.3 & 21.1 & 24.1 \\
\hline & \multicolumn{12}{|c|}{ Statistical values } \\
\hline Precent of rods measured & 45 & 97 & 97 & 99 & 70 & 97 & 47 & 98 & 95 & 99 & 67 & 97 \\
\hline \multicolumn{13}{|l|}{$\begin{array}{l}\text { Covariate ANOVA } \\
p \text {-values }\end{array}$} \\
\hline Pretreatment location & 0.01 & 0.0 & 0.0 & 0.0 & 0.03 & 0.06 & 0.66 & 0.03 & 0.00 & 0.00 & 0.19 & 0.15 \\
\hline Slope & 0.01 & 0.0 & 0.0 & 0.0 & 0.02 & 0.03 & 0.00 & 0.00 & 0.00 & 0.00 & 0.00 & 0.27 \\
\hline Treatment $\times$ slope & 0.41 & 0.0 & 0.0 & 0.0 & 0.0 & 0.01 & 0.73 & 0.47 & 0.54 & 0.01 & 0.60 & 0.70 \\
\hline
\end{tabular}


Table A2. 1993 percent soil water content in the 0 - to $0.35-\mathrm{m}$ depth layer by treatment and slope position. Percentage of all rod pairs measured successfully on each date is indicated, and the $p$-values for main effects of treatment site, slope position, and their interaction are provided.

\begin{tabular}{|c|c|c|c|c|c|c|c|c|c|c|c|c|}
\hline \multirow{3}{*}{ Treatment/slope } & \multicolumn{12}{|c|}{ Day of the year } \\
\hline & \multicolumn{6}{|c|}{ (Pretreatment dates) } & \multicolumn{6}{|c|}{ (During treatment dates) } \\
\hline & 14 & 55 & 119 & 142 & 161 & 193 & 204 & 222 & 243 & 274 & 299 & 327 \\
\hline & \multicolumn{12}{|c|}{ Measured values } \\
\hline \multicolumn{13}{|l|}{ Wet } \\
\hline Lower & 26.5 & 27.1 & 26.5 & 23.1 & 18.0 & 10.8 & 12.5 & 15.2 & 9.5 & 18.2 & 17.0 & 24.2 \\
\hline Middle & 25.9 & 26.7 & 26.0 & 20.9 & 14.1 & 9.2 & 9.3 & 12.5 & 7.0 & 15.2 & 12.7 & 22.6 \\
\hline Upper & 24.4 & 25.6 & 23.7 & 20.7 & 11.6 & 7.7 & 8.7 & 11.4 & 6.2 & 14.2 & 10.8 & 20.3 \\
\hline \multicolumn{13}{|l|}{ Ambient } \\
\hline Lower & 26.2 & 26.7 & 26.7 & 22.6 & 17.0 & 10.1 & 11.7 & 14.1 & 8.4 & 17.0 & 14.8 & 23.7 \\
\hline Middle & 24.6 & 24.5 & 24.4 & 20.1 & 14.3 & 9.1 & 9.1 & 11.4 & 6.7 & 14.6 & 11.5 & 21.5 \\
\hline Upper & 25.4 & 25.4 & 24.9 & 21.7 & 13.5 & 8.9 & 9.6 & 11.8 & 6.9 & 15.0 & 11.0 & 21.7 \\
\hline \multicolumn{13}{|l|}{ Dry } \\
\hline Lower & 24.2 & 24.9 & 24.0 & 19.4 & 13.0 & 7.8 & 9.6 & 11.0 & 6.7 & 13.0 & 10.2 & 18.8 \\
\hline Middle & 25.5 & 25.6 & 25.7 & 19.8 & 12.9 & 9.0 & 8.7 & 10.5 & 6.4 & 12.3 & 8.5 & 17.4 \\
\hline \multirow[t]{2}{*}{ Upper } & 24.7 & 25.1 & 24.0 & 19.4 & 11.3 & 8.2 & 7.9 & 9.7 & 6.1 & 11.4 & 7.8 & 16.0 \\
\hline & \multicolumn{12}{|c|}{ Statistical values } \\
\hline Percent of rods measured & 99 & 72 & 93 & 99 & 95 & 96 & 96 & 99 & 99 & 99.6 & 99.3 & 99.3 \\
\hline \multicolumn{13}{|l|}{ Covariate ANOVA $p$-values } \\
\hline Treatment & 0.76 & 0.33 & 0.91 & 0.15 & 0.28 & 0.37 & 0.04 & 0.00 & 0.00 & 0.00 & 0.00 & 0.00 \\
\hline Slope & 0.40 & 0.03 & 0.06 & 0.00 & 0.86 & 0.01 & 0.00 & 0.18 & 0.01 & 0.12 & 0.00 & 0.00 \\
\hline Treatment $\times$ slope & 0.98 & 0.44 & 0.92 & 0.06 & 0.59 & 0.05 & 0.02 & 0.13 & 0.04 & 0.09 & 0.07 & 0.04 \\
\hline Covariate & 0.00 & 0.00 & 0.00 & 0.00 & 0.00 & 0.00 & 0.00 & 0.00 & 0.00 & 0.00 & 0.00 & 0.00 \\
\hline
\end{tabular}


Table A3. 1993 percent soil water content in the 0- to 0.7-m depth layer by treatment and slope position.

Percentage of all rod pairs measured successfully on each date is indicated, and the $p$-values for main effects of treatment site, slope position, and their interaction are provided.

\begin{tabular}{|c|c|c|c|c|c|c|c|c|c|c|c|c|}
\hline \multirow{3}{*}{ Treatment/slope } & \multicolumn{12}{|c|}{ Day of the year } \\
\hline & \multicolumn{6}{|c|}{ (Pretreatment dates) } & \multicolumn{6}{|c|}{ (During treatment dates) } \\
\hline & 14 & 55 & 119 & 142 & 161 & 193 & 204 & 222 & 243 & 274 & 299 & 327 \\
\hline & \multicolumn{12}{|c|}{ Measured values } \\
\hline \multicolumn{13}{|l|}{ Wet } \\
\hline Lower & 26.3 & 25.9 & 25.3 & 22.6 & 17.7 & 10.8 & 11.7 & 14.2 & 11.0 & 16.8 & 17.8 & 22.2 \\
\hline Middle & 27.1 & 26.6 & 24.3 & 22.1 & 15.8 & 9.8 & 10.8 & 14.2 & 9.9 & 15.2 & 15.7 & 21.7 \\
\hline Upper & 25.6 & 25.1 & 24.9 & 20.7 & 14.6 & 8.6 & 9.6 & 12.3 & 8.8 & 14.1 & 13.3 & 19.3 \\
\hline \multicolumn{13}{|l|}{ Ambient } \\
\hline Lower & 26.2 & 26.5 & 26.1 & 23.1 & 18.0 & 11.5 & 12.1 & 14.3 & 11.0 & 16.1 & 16.5 & 21.9 \\
\hline Middle & 24.6 & 25.7 & 25.4 & 21.8 & 16.4 & 9.9 & 10.8 & 12.3 & 10.1 & 15.0 & 14.5 & 20.7 \\
\hline Upper & 25.4 & 24.7 & 26.0 & 21.8 & 15.6 & 9.5 & 9.6 & 12.0 & 9.2 & 14.2 & 13.1 & 20.1 \\
\hline \multicolumn{13}{|l|}{ Dry } \\
\hline Lower & 24.2 & 26.5 & 26.2 & 22.0 & 16.7 & 10.6 & 11.4 & 12.3 & 10.5 & 14.3 & 14.3 & 19.7 \\
\hline Middle & 25.5 & 27.0 & 26.5 & 21.9 & 15.8 & 10.0 & 10.1 & 11.6 & 9.2 & 12.3 & 11.4 & 16.8 \\
\hline \multirow[t]{2}{*}{ Upper } & 24.7 & 25.5 & 25.6 & 21.9 & 14.1 & 8.8 & 9.0 & 10.5 & 8.4 & 10.9 & 9.9 & 14.9 \\
\hline & \multicolumn{12}{|c|}{ Statistical values } \\
\hline Percent of rods measured & 92 & 78 & 96 & 91 & 97 & 96 & 94 & 93 & 94 & 96 & 94 & 96 \\
\hline \multicolumn{13}{|l|}{$\begin{array}{l}\text { Covariate ANOVA } \\
p \text {-values }\end{array}$} \\
\hline Treatment & 0.06 & 0.39 & 0.14 & 0.04 & 0.21 & 0.08 & 0.06 & 0.00 & 0.21 & 0.00 & 0.00 & 0.00 \\
\hline Slope & 0.00 & 0.00 & 0.06 & 0.01 & 0.03 & 0.18 & 0.11 & 0.09 & 0.15 & 0.95 & 0.40 & 0.00 \\
\hline Treatment $\times$ slope & 0.01 & 0.15 & 0.18 & 0.71 & 0.97 & 0.38 & 0.06 & 0.01 & 0.09 & 0.82 & 0.21 & 0.04 \\
\hline Covariate & 0.00 & 0.00 & 0.00 & 0.00 & 0.00 & 0.00 & 0.00 & 0.00 & 0.00 & 0.00 & 0.00 & 0.00 \\
\hline
\end{tabular}


Table A4. 1994 percent soil water content in the 0- to 0.35-m depth layer by treatment and slope position. Percentage of all rod pairs measured successfully on each date is indicated, and the $p$-values for main effects of treatment site, slope position, and their interaction are provided.

\begin{tabular}{|c|c|c|c|c|c|c|c|c|c|c|c|c|c|c|}
\hline \multirow{2}{*}{ Treatment/slope } & \multicolumn{14}{|c|}{ Day of the year } \\
\hline & 38 & 62 & 98 & 116 & 137 & 159 & 171 & 196 & 213 & 234 & 262 & 284 & 326 & 346 \\
\hline & \multicolumn{14}{|c|}{ Measured values } \\
\hline \multicolumn{15}{|l|}{ Wet } \\
\hline Lower & 24.6 & 25.8 & 25.4 & 22.3 & 23.4 & 21.2 & 22.9 & 23.2 & 23.1 & 25.9 & 23.9 & 24.0 & 22.9 & 26.2 \\
\hline Middle & 24.5 & 25.8 & 25.3 & 22.4 & 22.3 & 19.1 & 20.7 & 21.4 & 23.3 & 24.6 & 23.1 & 22.1 & 21.5 & 26.8 \\
\hline Upper & 23.3 & 24.2 & 24.7 & 21.6 & 22.2 & 18.2 & 19.0 & 19.9 & 22.5 & 23.9 & 22.3 & 19.3 & 19.3 & 25.5 \\
\hline \multicolumn{15}{|l|}{ Ambient } \\
\hline Lower & 24.4 & 25.3 & 25.3 & 21.5 & 22.4 & 19.9 & 20.5 & 21.9 & 23.7 & 24.5 & 22.9 & 22.3 & 21.1 & 24.9 \\
\hline Middle & 23.1 & 24.1 & 24.6 & 21.6 & 21.1 & 17.5 & 18.6 & 20.0 & 22.7 & 23.6 & 21.4 & 19.4 & 18.6 & 24.8 \\
\hline Upper & 24.2 & 24.9 & 25.1 & 21.7 & 22.1 & 17.5 & 17.4 & 19.1 & 21.6 & 22.4 & 20.8 & 17.3 & 17.0 & 25.2 \\
\hline \multicolumn{15}{|l|}{ Dry } \\
\hline Lower & 21.9 & 23.4 & 23.2 & 19.1 & 18.7 & 15.6 & 14.7 & 15.3 & 17.1 & 17.5 & 16.0 & 13.6 & 12.5 & 22.3 \\
\hline Middle & 23.5 & 24.8 & 24.4 & 20.4 & 18.6 & 13.6 & 12.8 & 12.7 & 14.1 & 14.8 & 14.7 & 12.5 & 10.7 & 22.6 \\
\hline Upper & 22.5 & 23.5 & 24.0 & 20.2 & 18.3 & 12.2 & 11.1 & 11.4 & 12.8 & 13.1 & 13.9 & 10.9 & 9.8 & 20.9 \\
\hline & \multicolumn{14}{|c|}{ Statistical values } \\
\hline Percent of rods measured & 99 & 100 & 99.3 & 98 & 99.6 & 98 & 99.3 & 99 & 99 & 96 & 99.3 & 98 & 99.3 & 99.7 \\
\hline \multicolumn{15}{|l|}{$\begin{array}{l}\text { Covariate ANOVA } \\
p \text {-values }\end{array}$} \\
\hline Treatment & 0.09 & 0.00 & 0.02 & 0.00 & 0.00 & 0.00 & 0.00 & 0.00 & 0.00 & 0.00 & 0.00 & 0.00 & 0.00 & 0.00 \\
\hline Slope & 0.00 & 0.11 & 0.32 & 0.00 & 0.06 & 0.00 & 0.00 & 0.00 & 0.58 & 0.00 & 0.01 & 0.00 & 0.00 & 0.09 \\
\hline Treatment $\times$ slope & 0.57 & 0.35 & 0.99 & 0.14 & 0.23 & 0.15 & 0.12 & 0.12 & 0.00 & 0.95 & 0.00 & 0.59 & 0.10 & 0.00 \\
\hline Covariate & .00 & .00 & .00 & .00 & .00 & .00 & .00 & .00 & .00 & .00 & .00 & .00 & .00 & .00 \\
\hline
\end{tabular}


Table A5. 1994 percent soil water content in the 0- to 0.7-m depth layer by treatment and slope position. Percentage of all rod pairs measured successfully on each date is indicated, and the $p$-values for main effects of treatment site, slope position, and their interaction are provided.

\begin{tabular}{|c|c|c|c|c|c|c|c|c|c|c|c|c|c|c|}
\hline \multirow{2}{*}{ Treatment/slope } & \multicolumn{14}{|c|}{ Day of the year } \\
\hline & 38 & 62 & 98 & 116 & 137 & 159 & 171 & 196 & 213 & 234 & 262 & 284 & 326 & 346 \\
\hline & \multicolumn{14}{|c|}{ Measured values } \\
\hline \multicolumn{15}{|l|}{ Wet } \\
\hline Lower & 23.6 & 26.0 & 26.2 & 23.1 & 23.1 & 20.4 & 21.8 & 23.1 & 22.9 & 24.5 & 22.4 & 21.8 & 24.1 & 24.6 \\
\hline Middle & 24.5 & 26.7 & 27.6 & 23.8 & 23.8 & 19.2 & 21.0 & 22.7 & 23.2 & 25.1 & 21.7 & 21.4 & 23.5 & 26.3 \\
\hline Upper & 23.2 & 25.8 & 26.5 & 22.8 & 22.8 & 18.4 & 19.5 & 22.1 & 22.0 & 23.4 & 20.3 & 20.5 & 22.4 & 25.0 \\
\hline \multicolumn{15}{|l|}{ Ambient } \\
\hline Lower & 24.5 & 25.7 & 25.9 & 23.4 & 23.4 & 19.4 & 20.0 & 22.7 & 23.2 & 24.5 & 21.7 & 21.1 & 23.0 & 25.2 \\
\hline Middle & 24.1 & 25.4 & 26.0 & 22.5 & 22.5 & 17.4 & 18.7 & 21.6 & 22.3 & 23.4 & 21.4 & 19.0 & 21.2 & 24.9 \\
\hline Upper & 24.0 & 25.8 & 25.7 & 23.1 & 23.1 & 16.8 & 17.4 & 20.3 & 20.9 & 21.6 & 19.2 & 16.5 & 19.4 & 24.2 \\
\hline Lower & 24.4 & 26.2 & 26.6 & 23.3 & 23.3 & 17.6 & 16.9 & 19.2 & 19.1 & 19.1 & 17.4 & 15.2 & 17.2 & 23.5 \\
\hline Middle & 24.4 & 26.4 & 27.0 & 23.6 & 23.6 & 15.7 & 14.9 & 15.8 & 15.8 & 15.3 & 14.5 & 13.0 & 14.1 & 21.9 \\
\hline \multirow[t]{2}{*}{ Upper } & 23.5 & 25.6 & 26.3 & 23.0 & 23.0 & 14.0 & 12.9 & 14.5 & 13.5 & 13.6 & 12.5 & 11.1 & 12.5 & 20.7 \\
\hline & \multicolumn{14}{|c|}{ Statistical values } \\
\hline Percent of rods measured & 98 & 100 & 96 & 100 & 100 & 99 & 99.3 & 97 & 99 & 98 & 99 & 98 & 100 & 100 \\
\hline \multicolumn{15}{|l|}{$\begin{array}{l}\text { Covariate ANOVA } \\
p \text {-values }\end{array}$} \\
\hline Treatment & 0.06 & 0.01 & 0.00 & 0.04 & 0.04 & 0.00 & 0.00 & 0.00 & $0: 00$ & 0.00 & 0.00 & 0.00 & 0.00 & 0.00 \\
\hline Slope & 0.00 & 0.00 & 0.00 & 0.00 & 0.00 & 0.02 & 0.00 & 0.03 & 0.01 & 0.00 & 0.00 & 0.00 & 0.00 & 0.04 \\
\hline Treatment $\times$ slope & 0.08 & 0.59 & 0.53 & 0.43 & 0.43 & 0.22 & 0.06 & 0.00 & 0.00 & 0.00 & 0.10 & 0.00 & 0.00 & 0.00 \\
\hline Covariate & .00 & .00 & .00 & .00 & .00 & .00 & .00 & .00 & .00 & .00 & .00 & .00 & .00 & .00 \\
\hline
\end{tabular}


Table A6. 1995 percent soil water content in the 0 - to $0.35-\mathrm{m}$ depth layer by treatment and slope position. Percentage of all rod pairs measured successfully on each date is indicated, and the $p$-values for main effects of treatment site, slope position, and their interaction are provided.

\begin{tabular}{|c|c|c|c|c|c|c|c|c|c|c|c|c|c|c|c|}
\hline \multirow{2}{*}{ Treatment/slope } & \multicolumn{15}{|c|}{ Day of the year } \\
\hline & 17 & 69 & 96 & 123 & 144 & 164 & 177 & 188 & 198 & 212 & 235 & 254 & 271 & 289 & 334 \\
\hline & \multicolumn{15}{|c|}{ Measured values } \\
\hline \multicolumn{16}{|l|}{ Wet } \\
\hline Lower & 26.3 & 26.8 & 24.4 & 26.3 & 24.8 & 19.6 & 16.4 & - & 10.2 & 10.6 & 13.2 & 8.8 & 19.1 & 21.4 & 25.7 \\
\hline Middle & 25.8 & 26.6 & 24.0 & 25.4 & 24.3 & 17.3 & 13.7 & - & 8.0 & 8.8 & 11.2 & 7.1 & 17.7 & 19.8 & 25.5 \\
\hline Upper & 25.4 & 26.7 & 23.3 & 25.0 & 23.6 & 18.2 & 14.1 & 11.5 & 8.2 & 8.7 & 10.1 & 6.4 & 17.2 & 19.1 & 25.1 \\
\hline \multicolumn{16}{|l|}{ Ambient } \\
\hline Lower & 25.3 & 26.0 & 23.5 & 25.3 & 24.0 & 18.3 & 14.2 & - & 8.9 & 9.4 & 11.9 & 8.6 & 17.2 & 19.1 & 25.6 \\
\hline Middle & 24.7 & 25.6 & 23.0 & 24.1 & 23.8 & 16.6 & 12.4 & - & 7.8 & 8.4 & 10.4 & 7.8 & 16.1 & 18.5 & 25.2 \\
\hline Upper & 24.7 & 25.6 & 22.5 & 24.1 & 23.7 & 16.8 & 11.7 & 9.6 & 7.5 & 8.2 & 9.4 & 5.9 & 16.6 & 17.8 & 24.4 \\
\hline \multicolumn{16}{|l|}{ Dry } \\
\hline Lower & 23.1 & 23.7 & 21.3 & 23.2 & 21.7 & 15.4 & 10.3 & - & 7.3 & 8.0 & 9.3 & 6.3 & 12.8 & 14.4 & 22.8 \\
\hline Middle & 23.8 & 25.2 & 22.5 & 23.5 & 23.0 & 14.3 & 9.6 & - & 7.4 & 8.0 & 9.4 & 7.2 & 13.2 & 14.8 & 24.1 \\
\hline \multirow[t]{2}{*}{ Upper } & 22.2 & 23.6 & 20.6 & 22.3 & 20.9 & 12.7 & 8.7 & 8.6 & 7.0 & 7.1 & 7.3 & 5.5 & 12.0 & 11.5 & 21.8 \\
\hline & \multicolumn{15}{|c|}{ Statistical values } \\
\hline $\begin{array}{l}\text { Percent of rods } \\
\text { measured }\end{array}$ & 99.7 & 99.7 & 99.7 & 100 & 99 & 97 & 99 & 40 & 99 & 99 & 99.7 & 48 & 99.3 & 96 & 99.7 \\
\hline \multicolumn{16}{|l|}{$\begin{array}{l}\text { Covariate ANOVA } \\
p \text {-values }\end{array}$} \\
\hline Treatment & 0.00 & 0.00 & 0.00 & 0.00 & 0.01 & 0.00 & 0.00 & 0.00 & 0.00 & 0.00 & 0.00 & 0.18 & 0.00 & 0.00 & 0.00 \\
\hline Slope & 0.00 & 0.00 & 0.00 & 0.00 & 0.00 & 0.69 & 0.77 & - & 0.35 & 0.84 & 0.00 & 0.00 & 0.00 & 0.00 & 0.18 \\
\hline Treatment $\times$ slope & 0.01 & 0.01 & 0.09 & 0.03 & 0.03 & 0.00 & 0.29 & - & 0.68 & 0.80 & 0.77 & 0.34 & 0.14 & 0.00 & 0.54 \\
\hline Covariate & .00 & .00 & .00 & .00 & .00 & .00 & .00 & 0.00 & .00 & .00 & .00 & .00 & .00 & .00 & .00 \\
\hline
\end{tabular}


Table A7. 1995 percent soil water content in the $0-$ to $0.7-\mathrm{m}$ depth layer by treatment and slope position. Percentage of all rod pairs measured successfully on each date is indicated, and the $p$-values for main effects of treatment site, slope position, and their interaction are provided.

\begin{tabular}{|c|c|c|c|c|c|c|c|c|c|c|c|c|c|c|c|}
\hline \multirow{2}{*}{ Treatment/slope } & \multicolumn{15}{|c|}{ Day of the year } \\
\hline & 17 & 69 & 96 & 123 & 144 & 164 & 177 & 188 & 198 & 212 & 235 & 254 & 271 & 289 & 334 \\
\hline & \multicolumn{15}{|c|}{ Measured values } \\
\hline \multicolumn{16}{|l|}{ Wet } \\
\hline Lower & 25.6 & 27.3 & 23.8 & 26.4 & 22.8 & 20.0 & 17.8 & - & 10.8 & 11.3 & 12.9 & - & 17.7 & 21.8 & 21.1 \\
\hline Middle & 27.5 & 28.2 & 23.9 & 26.8 & 23.0 & 19.3 & 17.6 & - & 10.6 & 11.3 & 13.1 & 一 & 17.9 & 21.6 & 23.7 \\
\hline Upper & 26.4 & 27.4 & 24.4 & 26.1 & 23.3 & 20.0 & 17.5 & - & 10.0 & 10.8 & 12.4 & - & 18.1 & 20.6 & 19.8 \\
\hline \multicolumn{16}{|l|}{ Ambient } \\
\hline Lower & 26.7 & 27.4 & 24.4 & 26.8 & 22.9 & 19.4 & 17.4 & - & 11.5 & 11.8 & 12.9 & - & 14.2 & 20.3 & 21.8 \\
\hline Middle & 26.4 & 26.8 & 23.3 & 26.5 & 23.7 & 19.4 & 16.7 & - & 10.2 & 10.7 & 11.9 & - & 15.4 & 19.5 & 22.4 \\
\hline Upper & 25.5 & 26.6 & 23.7 & 25.0 & 22.3 & 16.4 & 14.8 & - & 9.4 & 10.0 & 11.2 & - & 13.5 & 17.8 & 19.5 \\
\hline \multicolumn{16}{|l|}{ Dry } \\
\hline Lower & 26.2 & 26.9 & 23.7 & 26.0 & 23.1 & 18.6 & 15.2 & - & 10.4 & 11.2 & 12.0 & 一 & 14.4 & 17.9 & 21.1 \\
\hline Middle & 25.9 & 27.4 & 22.5 & 25.5 & 23.3 & 17.0 & 14.3 & - & 9.5 & 10.1 & 10.8 & - & 13.7 & 15.2 & 22.0 \\
\hline \multirow[t]{2}{*}{ Upper } & 24.9 & 26.3 & 23.8 & 24.8 & 22.4 & 15.4 & 12.6 & - & 8.5 & 9.3 & 10.3 & - & 11.2 & 13.4 & 18.7 \\
\hline & \multicolumn{15}{|c|}{ Statistical values } \\
\hline $\begin{array}{l}\text { Percent of rods } \\
\text { measured }\end{array}$ & 99.7 & 97 & 100 & 98 & 97 & 100 & 99 & 0 & 97 & 98 & 95 & 0 & 49 & 93 & 96 \\
\hline \multicolumn{16}{|l|}{$\begin{array}{l}\text { Covariate ANOVA } \\
p \text {-values }\end{array}$} \\
\hline Treatment & 0.00 & 0.00 & 0.07 & 0.00 & 0.47 & 0.00 & 0.00 & - & 0.00 & 0.00 & 0.00 & 一 & 0.00 & 0.00 & 0.38 \\
\hline Slope & 0.00 & 0.00 & 0.00 & 0.00 & 0.00 & 0.13 & 0.12 & - & 0.31 & 0.66 & 0.58 & - & 0.59 & 0.03 & 0.00 \\
\hline Treatment $\times$ slope & 0.01 & 0.32 & 0.09 & 0.06 & 0.36 & 0.00 & 0.10 & - & 0.20 & 0.11 & 0.05 & - & 0.22 & 0.01 & 0.79 \\
\hline Covariate & .00 & .00 & .00 & .00 & .00 & .00 & .00 & - & .00 & .00 & .00 & - & .00 & .00 & .00 \\
\hline
\end{tabular}


Table A8. 1996 percent soil water content in the 0- to 0.35-m depth layer by treatment and slope position. Percentage of all rod pairs measured successfully on each date is indicated, and the $p$-values for main effects of treatment site, slope position, and their interaction are provided.

\begin{tabular}{|c|c|c|c|c|c|c|c|c|c|c|c|c|c|c|c|c|c|}
\hline \multirow{2}{*}{ Treatment/slope } & \multicolumn{17}{|c|}{ Day of the year } \\
\hline & 25 & 60 & 87 & 120 & 142 & 159 & 173 & 184 & 198 & 214 & 229 & 243 & 257 & 270 & 284 & 305 & 339 \\
\hline & \multicolumn{17}{|c|}{ Measured values } \\
\hline \multicolumn{18}{|l|}{ Wet } \\
\hline Lower & 28.1 & 24.9 & 25.5 & 24.6 & 24.2 & 22.7 & 22.7 & 19.5 & 23.3 & 25.9 & 23.8 & 18.2 & 16.3 & 17.2 & 20.7 & 21.9 & 25.8 \\
\hline Middle & 28.4 & 24.4 & 24.6 & 23.4 & 23.6 & 20.7 & 21.2 & 17.9 & 19.8 & 26.7 & 23.2 & 16.8 & 14.6 & 16.2 & 19.6 & 20.0 & 25.8 \\
\hline Upper & 27.7 & 23.8 & 24.0 & 22.8 & 23.3 & 20.0 & 22.7 & 17.6 & 20.3 & 27.6 & 22.2 & 18.3 & 15.2 & 15.4 & 19.7 & 19.1 & 26.2 \\
\hline \multicolumn{18}{|l|}{ Ambient } \\
\hline Lower & 27.8 & 24.5 & 24.1 & 24.7 & 23.1 & 21.5 & 21.6 & 18.6 & 21.6 & 27.1 & 24.1 & 17.2 & 15.5 & 16.4 & 19.1 & 20.0 & 24.9 \\
\hline Middle & 27.7 & 23.7 & 24.0 & 21.9 & 22.9 & 21.2 & 22.7 & 17.5 & 19.1 & 25.1 & 23.1 & 16.9 & 14.2 & 15.3 & 18.2 & 17.6 & 25.1 \\
\hline Upper & 27.9 & 24.0 & 24.3 & 22.8 & 23.1 & 19.9 & 21.8 & 17.0 & 20.4 & 25.8 & 22.2 & 16.5 & 13.5 & 14.1 & 17.1 & 16.0 & 25.6 \\
\hline \multicolumn{18}{|l|}{ Dry } \\
\hline Lower & 25.4 & 22.0 & 22.4 & 23.4 & 19.5 & 19.1 & 19.3 & 15.2 & 18.4 & 23.7 & 21.4 & 14.0 & 11.2 & 11.5 & 13.1 & 14.2 & 22.8 \\
\hline Middle & 27.3 & 24.1 & 24.3 & 23.3 & 21.7 & 19.8 & 21.6 & 15.7 & 16.1 & 23.9 & 21.9 & 14.3 & 11.0 & 11.1 & 12.7 & 12.8 & 25.1 \\
\hline Upper & 26.4 & 22.4 & 22.5 & 21.7 & 20.0 & 16.8 & 20.7 & 12.8 & 15.3 & 24.4 & 19.4 & 12.8 & 8.9 & 9.3 & 11.0 & 10.2 & 23.6 \\
\hline & \multicolumn{17}{|c|}{ Statistical values } \\
\hline $\begin{array}{l}\text { Percent of rods } \\
\text { measured }\end{array}$ & 92 & 97 & 97 & 91 & 97 & 98 & 98 & 99 & 93 & 99 & 99.3 & 87 & 97 & 96 & 97 & 99 & 97 \\
\hline \multicolumn{18}{|l|}{$\begin{array}{l}\text { Covariate ANOVA } \\
p \text {-values }\end{array}$} \\
\hline Treatment & 0.13 & 0.68 & 0.52 & 0.75 & 0.00 & 0.00 & 0.15 & 0.00 & 0.00 & 0.07 & 0.00 & 0.00 & 0.00 & 0.00 & 0.00 & 0.00 & 0.03 \\
\hline Slope & 0.27 & 0.48 & 0.36 & 0.00 & 0.14 & 0.00 & 0.03 & 0.00 & 0.00 & 0.38 & 0.00 & 0.39 & 0.00 & 0.00 & 0.05 & 0.00 & 0.00 \\
\hline Treatment $\times$ slope & 0.88 & 0.68 & 0.38 & 0.27 & 0.53 & 0.18 & 0.01 & 0.33 & 0.40 & 0.62 & 0.41 & 0.07 & 0.13 & 0.73 & 0.70 & 0.00 & 0.06 \\
\hline Covariate & .00 & .00 & .00 & .00 & .00 & .00 & .00 & 0.00 & .00 & .00 & .00 & .00 & 0.00 & .00 & .00 & .00 & 0.00 \\
\hline
\end{tabular}


Table A9. 1996 percent soil water content in the 0 - to $0.7-\mathrm{m}$ depth layer by treatment and slope position. Percentage of all rod pairs measured successfully on each date is indicated, and the $p$-values for main effects of treatment site, slope position, and their interaction are provided.

\begin{tabular}{|c|c|c|c|c|c|c|c|c|c|c|c|c|c|c|c|c|c|}
\hline \multirow{2}{*}{ Treatment/slope } & \multicolumn{17}{|c|}{ Day of the year } \\
\hline & 25 & 60 & 87 & 120 & 142 & 159 & 173 & 184 & 198 & 214 & 229 & 243 & 257 & 270 & 284 & 305 & 339 \\
\hline & \multicolumn{17}{|c|}{ Measured values } \\
\hline \multicolumn{18}{|l|}{ Wet } \\
\hline Lower & 26.0 & 24.9 & 25.3 & - & 24.1 & 21.0 & 21.6 & 20.6 & 22.6 & 27.2 & 23.1 & 18.7 & 20.1 & 17.4 & 19.5 & 20.3 & 25.3 \\
\hline Middle & 27.0 & 25.7 & 26.2 & - & 22.8 & 22.7 & 21.6 & 20.5 & 21.5 & 26.9 & 23.8 & 19.2 & 20.1 & 17.2 & 19.3 & 20.3 & 26.1 \\
\hline Upper & 26.4 & 24.9 & 25.5 & - & 22.2 & 21.1 & 22.2 & 20.1 & 20.4 & 25.8 & 23.5 & 19.4 & 19.2 & 18.0 & 19.7 & 20.0 & 25.3 \\
\hline \multicolumn{18}{|l|}{ Ambient } \\
\hline Lower & 26.4 & 25.5 & 25.6 & - & 24.3 & 21.8 & 22.3 & 20.3 & 21.4 & 27.7 & 24.0 & 19.5 & 21.1 & 17.8 & 19.5 & 19.5 & 25.8 \\
\hline Middle & 26.1 & 25.2 & 25.1 & - & 22.4 & 22.1 & 21.9 & 20.2 & 20.7 & 25.8 & 23.7 & 19.3 & 20.8 & 16.6 & 18.0 & 18.5 & 25.2 \\
\hline Upper & 26.4 & 24.7 & 25.1 & - & 22.3 & 21.2 & 23.0 & 19.5 & 18.4 & 24.8 & 22.8 & 17.9 & 16.2 & 14.8 & 16.2 & 16.3 & 24.6 \\
\hline \multicolumn{18}{|l|}{ Dry } \\
\hline Lower & 26.2 & 25.3 & 25.6 & - & 23.5 & 21.2 & 21.2 & 19.0 & 19.4 & 26.2 & 23.6 & 18.6 & 19.1 & 15.9 & 16.3 & 16.4 & 25.6 \\
\hline Middle & 26.3 & 25.3 & 25.9 & - & 21.7 & 21.6 & 21.4 & 18.4 & 17.2 & 25.4 & 22.7 & 17.5 & 16.0 & 13.8 & 14.4 & 14.6 & 25.7 \\
\hline Upper & 26.0 & 24.0 & 24.9 & - & 21.2 & 19.4 & 21.0 & 16.9 & 16.3 & 25.3 & 21.5 & 15.4 & 14.0 & 12.4 & 12.3 & 12.4 & 24.6 \\
\hline & \multicolumn{17}{|c|}{ Statistical values } \\
\hline $\begin{array}{l}\text { Percent of rods } \\
\text { measured }\end{array}$ & 98 & 97 & 99 & 0 & 96 & 96 & 78 & 97 & 99 & 99.3 & 96 & 99 & 96 & 96 & 99 & 96 & 99 \\
\hline \multicolumn{18}{|l|}{$\begin{array}{l}\text { Covariate ANOVA } \\
p \text {-values }\end{array}$} \\
\hline Treatment & 0.10 & 0.10 & 0.84 & - & 0.00 & 0.00 & 0.00 & 0.00 & 0.00 & 0.04 & 0.00 & 0.00 & 0.00 & 0.00 & 0.00 & 0.00 & 0.02 \\
\hline Slope & 0.00 & 0.13 & 0.68 & - & 0.00 & 0.00 & 0.22 & 0.14 & 0.00 & 0.00 & 0.07 & 0.02 & 0.00 & 0.48 & 0.18 & 0.00 & 0.07 \\
\hline Treatment $\times$ slope & 0.10 & 0.49 & 0.27 & - & 0.94 & 0.14 & 0.36 & 0.35 & 0.74 & 0.33 & 0.05 & 0.00 & 0.01 & 0.00 & 0.00 & 0.00 & 0.07 \\
\hline Covariate & .00 & .00 & .00 & - & .00 & .00 & .00 & 0.00 & .00 & .00 & .00 & .00 & 0.00 & .00 & .00 & .00 & 0.00 \\
\hline
\end{tabular}




\section{INTERNAL DISTRIBUTION}

1. J. Amthor

2. L. Cooper

3. J. H. Cushman

4. N. T. Edwards

5. D. E. Fowler

6. C. T. Garten, Jr.

7. M. Gebre

8. C. A. Gunderson

9-60. P. J. Hanson

61. S. G. Hildebrand

62. M. Huston

63. D. Huff

64. G. K. Jacobs

65. P. M. Jardine

66. P. Kanciruk

67. A. W. King

68. S. E. Lindberg

69. J. M. Loar
70. G. M. Logsdon

71. R. J. Luxmoore

72. S. B. McLaughlin

73. P. J. Mulholland

74. T. E. Myrick

75. R. J. Norby

76. R. J. Olson

77. E. G. O'Neill

78. W. M. Post

79. D. E. Reichle

80. D. S. Shriner

81. T. J. Tschaplinski

82. S. D. Wullschleger

83. Central Research Library

84-86. ESD Library

87-88. Laboratory Records Dept.

89. ORNL Laboratory Records-RC

\section{EXTERNAL DISTRIBUTION}

90. M. Broido, Director, Environmental Sciences Division, ER-74, Department of Energy, 19901 Germantown Road, Germantown, MD 20874

91. E. G. Cumesty, ORNL Site Manager, Department of Energy, Oak Ridge National Laboratory, P.O. Box 2008, Oak Ridge, TN 37831-6269

92. R. Dahlman, Environmental Sciences Division, ER-74, U.S. Department of Energy, 19901 Germantown Road, Germantown, MD 20874

93. J. Elwood, Environmental Sciences Division, ER-74, U.S. Department of Energy, 19901 Germantown Road, Germantown, MD 20874

94. M. C. MacCracken, Director, Office of the U.S. Global Change Research Program, Code YS-1, 300 E Street, SW, Washington, DC 20546

95. Office of Assistant Manager for Energy Research and Development, U.S. Department of Energy, Oak Ridge Operations, P.O. Box 2001, Oak Ridge, TN 37831-8600

96-97. Office of Scientific and Technical Information, P.O. Box 62, Oak Ridge, TN 37831

98. A. Patrinos, Associate Director, Office of Health and Environmental Research, ER-70, Department of Energy, 19901 Germantown Road, Germantown, MD 20874 